\title{
Has the CISG Advisory Council Come of Age?
}

\author{
Joshua D. H. Karton \& Lorraine de Germiny*
}

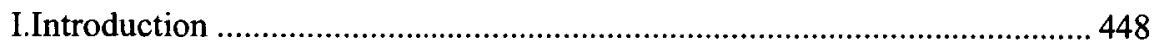

II.The CISG Advisory Council ................................................................. 452

A. Foundation and Composition of the CISG Advisory Council....... 452

B. The Goal of Uniform Interpretation.......................................... 457

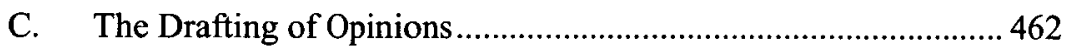

D. The CISG Advisory Council Compared ....................................... 464

III.The Impact of the CISG Advisory Council on the Uniform

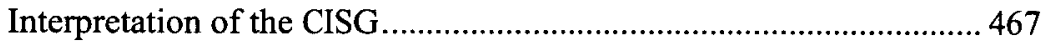

A. The Opinions of the Advisory Council ........................................ 469

B. The Legal Status of Advisory Council Opinions .......................... 473

C. Citation of CISG-AC Opinions by Courts and Arbitral

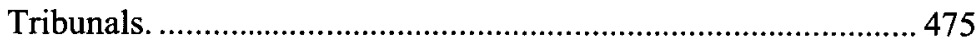

D. Receipt of CISG-AC Opinions by the Academic Community...... 478

IV.The CISG Advisory Council in the Global Jurisconsultorium ....................483

A. Centralized and Decentralized Interpretation of the CISG............ 484

B. The Proper Role of the CISG-AC ............................................. 491

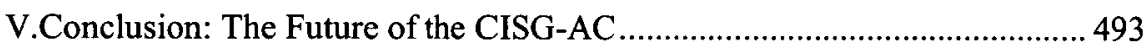

I.

INTRODUCTION

A well-functioning commercial system requires a high degree of legal certainty; businesses will hesitate to enter into contractual relationships if they are unable to forecast the risks associated with breakdowns in those

\footnotetext{
* PhD Candidate, University of Cambridge, and Associate, King \& Spalding, respectively. The authors would like to thank several members of the CISG Advisory Council who helped us by granting interviews and by reviewing drafts of this article: Eric Bergsten, Sieg Eiselen, Albert Kritzer, Loukas Mistelis, Pilar Perales Viscasillas, and, in particular, Alejandro Garro, who first suggested this topic to us.
} 
relationships. Traditionally, in any dispute involving one or more foreign parties, courts would apply their domestic private international law rules to choose a national law to govern the dispute. The result was that a "panoply of different domestic laws and systems" governed international contractual disputes. ${ }^{1}$ However, commercial practices do not track national borders, and traders in a particular industry tend to have more in common with foreign firms in the same line of business than with their neighbors plying different trades. Thus, "[t]he universality of commercial practice provides the opportunity to structure a uniform law of sales premised upon the commonality of practice." 2

Building on earlier, less successful efforts to create such a law, ${ }^{3}$ in 1980 , the United Nations Commission on International Trade Law ("UNCITRAL") adopted the Convention on Contracts for the International Sale of Goods ("CISG"). ${ }^{4}$ The CISG is' a treaty that acts as a commercial code for international sales transactions. Many of its provisions are borrowed from common law or civil law concepts, or represent a compromise between the two, but its drafters "took great strides to root out words that carry "domestic baggage." 5 Described as the "lingua franca of sales,"6 the CISG has been ratified by seventy-three countries, including every major trading nation except the $\mathrm{UK}^{7}$

1. Larry A. Dimatteo, Lucien J. Dhooge, Stephanie Greene, Virginia G. Maurer, and Marisa ANNe Pagnattaro, INTERnational Sales law: A Critical analysis of CisG JURISPRUDENCE 11 (2005).

2. Id. at 1 .

3. The most notable examples are two instruments promulgated at the 1964 Hague Convention: the Uniform Law on the International Sale of Goods and the Uniform Law on the Formation of Contracts for the International Sale of Goods, which failed to be adopted by a significant number of states, in large part due to the perception that they were biased toward the interests of western countries. Franco Ferrari, Uniform Interpretation of the 1980 Uniform Sales Law, 24 GA. J. INT'L \& COMP. L. 183, 190-92 (1994). See generally JOHN O. HONNOLD, DOCUMENTARY HISTORY OF THE UNIFORM LAW FOR INTERNATIONAL SALES: THE STUDIES, DELIBERATIONS, AND DECISIONS THAT LED TO THE 1980 UNITED NATIONS CONVENTION WITH INTRODUCTIONS AND EXPLANATIONS (1989) [hereinafter HONNOLD, DOCUMENTARY HISTORY].

4. UNCITRAL is the United Nations' primary trade law body and one of the most important institutions in international private law. It is composed of representatives from sixty UN member states and has a mandate to promote the progressive harmonization and unification of international trade law. To this end, its primary business is the preparation of treaties, model laws, rules of procedure, and interpretive guides on international private law topics. Besides the CISG, the bestknown UNCITRAL products are its Model Law on International Commercial Arbitration, which has been adopted by more than sixty countries, and its Arbitration Rules, which are used extensively in ad hoc international arbitrations. See Uncitral.org, About UNCITRAL, http://www.uncitral.org /uncitral/en/about_us.html (last visited March 9, 2009).

5. Vikki M. Rogers \& Albert H. Kritzer, A Uniform International Sales Terminology, in FESTSCHRIFT FÜR PETER SCHLECHTRIEM 223, 224 (Ingeborg Schwenzer \& Günter Hager eds., 2003) (citing John $\mathrm{O}$. Honnold, Uniform Laws for International Trade: Early "Care and Feeding" for Uniform Growth, 1 INT'L TRADE \& BUS. L.J. 1 (1995)).

6. Peter Schlechtriem, Requirements of Application and Sphere of Applicability of the CISG, 36 VICT. U. WELLINGTON L. REV. 781, 782 (2005).

7. For the current status of the CISG, see http://www.uncitral.org/uncitral/en/uncitral_texts/ 
The "international character"8 of the CISG "implies that its overall purpose is the standardization of law at a level above that of national law." However, to achieve such standardization, it is "insufficient to merely create and enact uniform instruments." 10 As R.J.C. Munday stated in a much-quoted passage, "even when outward uniformity is achieved, . . . uniform application of the agreed rules is by no means guaranteed, as in practice different countries almost inevitably come to put different interpretations upon the same enacted words." 11 If courts allow themselves to be influenced by their own national laws and modes of legal reasoning, "infusing domestic notions" into the CISG threatens the "assurances of predictability of outcome" that were the rationale for the CISG's enactment. ${ }^{12}$ Some critics have even argued that the exhibition of a "homeward trend" by national courts nullifies the benefits that a uniform sales law would theoretically provide. ${ }^{13}$

What is needed is a "follow up mechanism" to police divergent applications and to help bring the unruly mass of independent courts and tribunals into some common order. ${ }^{14}$ In domestic legal systems or institutions

sale_goods/1980CISG_status.html.

8. United Nations Convention On Contracts For The International Sales of Goods art. 7(1), Apr. 11, 1980, 52 Fed. Reg. 6262, 6264-6280, 1489 U.N.T.S. 3, 59 [hereinafter CISG].

9. DiMATTEO ET AL., supra note 1, at 8-9. As Enderlein and Maskow put it, conventions such as the CISG are different from uniform laws in that: "[T]here is a difference with uniform laws insofar as this incorporation elucidates the international character of the prospective rule, underlines its special position in domestic law, and furthers an interpretation and application which is oriented to the standardization of law." FRITZ ENDERLEIN \& DIETRICH MASKOW, INTERNATIONAL SaLeS LAW 8 (1992).

10. Franco Ferrari, The CISG's Uniform Interpretation by Courts-An Update, 9 V. J. INT'L COM. L. \& ARB. 233 (2005). For variations on this often-expressed sentiment, see also Camilla Baasch Andersen, The Uniform International Sales Law and the Global Jurisconsultorium, 24 J.L. \& COM. 159, 162 (2005) ("drafting uniform words is one thing; ensuring their uniformity is another"); Ralph Amissah, The Autonomous Contract: Reflecting the Borderless Electronic-Commercial Environment in Contracting (1997), available at http://www.jus.uio.no//m/the. autonomous.contract.07.10.1997.amissah/doc.html; Lisa M. Ryan, The Convention on Contracts for the International Sale of Goods: Divergent Interpretations, 4 TUL. J. INT'L \& COMP. L. 99, 117 (1995) ("textual uniformity . . is insufficient"); John O. Honnold, The Sales Convention in ActionUniform International Words: Uniform Application?, 8 J.L. \& COM. 207 (1988).

11. R.J.C. Munday, The Uniform Interpretation of International Conventions, 27 INT'L \& COMP. L.Q. 450 (1978).

12. Rogers \& Kritzer, supra note 5, at 224. Of course, this concern applies not just to the CISG, but to any international convention that may govern cases decided in national courts or arbitral tribunals. For example, Briggs notes that, although the E.U.'s Convention on the Law Applicable to Contractual Obligations (Rome 1980) derives in large part from common law principles, its status "as an international text means that pressure for it to receive a uniform interpretation will inevitably draw it away from any common law ancestry which it may have had." ADRIAN BRIGGS, THE CONFLICT OF LAWS 148 (2002).

13. For a summary ultimately rejecting such arguments, see DIMATTEO ET AL., supra note 1, at $\mathbf{x i}$.

14. Interview with Dr. Loukas Mistelis, former CISG Advisory Council Secretary and Clive M. Schmitthoff Professor of Transnational Commercial Law, Queen Mary, University of London, in London (June 4, 2008) [hereinafter Mistelis interview]. 
like the European Union, courts with final appellate authority help to enforce uniform interpretation. ${ }^{15}$ Otherwise, consultative bodies can help guide uniform interpretation, as the American Law Institute does in the United States and the International Law Commission does with respect to public international law. For the CISG, there is neither a supreme court nor a well-established consultative body. Instead, national courts, arbitral tribunals, scholarly commentators, and UNCITRAL all contribute to the international corpus of interpretive wisdom. This unorganized community of interpreters has been called the "global jurisconsultorium," "the phenomenon of the meeting of minds across jurisdictions in the shaping of international law." 16

In 2001, the International Sales Convention Advisory Council ("the CISGAC" or "the Advisory Council") inserted itself into this jurisconsultorium. Composed of prominent international sales law scholars from around the world, the Advisory Council discusses and renders opinions on unsettled matters of CISG interpretation. An unofficial "private initiative," the CISG-AC is jointly sponsored by the Institute of International Commercial Law at Pace University School of Law and the Centre for Commercial Law Studies at Queen Mary, University of London. ${ }^{17}$ As its members describe it, the Advisory Council has three main functions: to promote understanding and uniform interpretation of the CISG by publishing opinions on issues of interpretation, to promote the CISG generally, and to encourage and assist with the adoption and implementation of the CISG in jurisdictions that have not ratified it. ${ }^{18}$

Our focus here is on the Advisory Council's principal role: promoting uniform interpretation of the CISG. ${ }^{19}$ As an unofficial body, it can be effective only if it persuades academic commentators and, in particular, courts and arbitral tribunals to adopt the interpretations it proffers. In its first few years of operation, it received little response, at least in the English-speaking world. However, in the last two years, a significant number of academic articles referring to the Advisory Council have been published. More significantly, one

15. Some have called for the establishment of a global court with final appellate authority over international conventions. See, e.g., KONRAD ZWEIGERT \& HEIN KÖTZ, INTRODUCTION TO COMPARATIVE LAW 21 (Tony Weir, tr., 3d ed. 1998) ("The only sure way to avoid national divergences in the construction and development of uniform law is to grant jurisdiction to an international court.").

16. Andersen, supra note 10, at 159-160; see also Rogers \& Kritzer, supra note 5, at 228.

17. Loukas Mistelis, CISG-AC Publishes First Opinion, 15 PACE INT'L L. REV. 453, 455 (2003).

18. Mistelis interview, supra note 14. As the Draft Charter states, an early idea was that the Advisory Council would work toward completion of a comprehensive commentary on the CISG. However, the members eventually rejected this idea. Several members either had already written or were in the process of writing their own commentaries. In addition, it was thought that a commentary should have a more individualized point of view.

19. This is not to minimize the importance of the other two goals. The main factor hindering the development of the CISG may well be that most lawyers are not sufficiently familiar with it, or even aware of its existence. As a result, in many cases in which the CISG potentially applies, it is not pled by either party. 
of its opinions was cited as authoritative in a U.S. Federal District Court decision, TeeVee Toons, Inc. and Steve Gottlieb, Inc. v. Gerhard Schubert $G \mathrm{mbH} .^{20}$ Prompted by these developments, we ask whether the Advisory Council has now "come of age"?

This article is not concerned with whether any particular interpretation of the CISG put forward by the AC is correct, but rather the role that it plays in the global jurisconsultorium. We begin, in section II, by describing the Advisory Council, its foundation, membership, mission, and procedures. Next, in section III, we look at the impact of the Advisory Council on the interpretation of the CISG, including its reception by adjudicators and academics. This study lays the groundwork for our exploration in section IV of the Advisory Council's place in the CISG interpretive community and its role in the development of international sales law. We conclude in section $\mathrm{V}$ by describing why we believe that the CISG Advisory Council has "come of age" and by offering some thoughts on the Advisory Council's future.

\section{II.}

\section{THE CISG ADVISORY COUNCIL}

In this section, we first look at the formation and membership of the Advisory Council (A). Next, we examine the principle of interpretive uniformity, the promotion of which is the Advisory Council's primary goal (B). We then consider the process by which the Advisory Council drafts its opinions (C) and compare the Advisory Council to other advisory bodies and institutions that promote uniform laws and the harmonization of law (D).

\section{A. Foundation and Composition of the CISG Advisory Council}

The idea of a CISG interpretive committee was debated over the course of several years in meetings of various international organizations, and in those of UNCITRAL in particular. ${ }^{21}$ Credit for first proposing an interpretive committee is given to Professor Michael Joachim Bonell, an Italian delegate to UNCITRAL, who in 1987 called for the creation of a "permanent editorial board" composed of representatives from the CISG signatory states. ${ }^{22}$ Such composition would ensure that the member states would receive "equal attention ... without giving any State or region a privileged position for political, economic or purely linguistic reasons." 23 The delegates would collect and

20. TeeVee Toons, Inc. v. Gerhard Schubert GmbH, 2006 U.S. Dist. LEXIS 59455 at 14 (S.D.N.Y. 2006).

21. See Mistelis, supra note 17, at 454 .

22. Mistelis interview, supra note 14.

23. UNCITRAL, Report on the work of its $21^{\text {st }}$ Session, 19 UNCITRAL Y.B. 1 (1988) 16, U.N. Doc. A/43/17, I 107; See also Spiros V. Bazinas, Uniformity in the Interpretation and the Application of the CISG: The Role of CLOUT and the Digest, 17, 20, presented in "Celebrating 
report annually on court decisions from their home states interpreting the CISG and provide a comparative analysis of these decisions. ${ }^{24}$ They could also render non-binding advice regarding the interpretation of specific CISG provisions, either at the request of a court or parties to a dispute or of their own initiative. ${ }^{25}$

However, the UNCITRAL Commission (composed of representatives of the member states) rejected Professor Bonell's proposal, calling it "too ambitious or at least premature." 26 In the Commission's eyes, the operation of such an institution would be "unwieldy" in view of the large number of CISG signatories. ${ }^{27}$ It was also concerned that a national representative's analysis of a court's interpretation of a CISG provision would appear to "represent an authoritative opinion of the member state." 28 Most importantly, because the CISG becomes incorporated into a state's national laws upon ratification, the UNCITRAL Commission did not want to intervene in what would amount to national courts' interpretations of their own domestic laws. ${ }^{29}$ The prospect of countries surrendering even this small measure of sovereignty to an international body made approval of a permanent advisory body unlikely. ${ }^{30}$

Although no official CISG interpretive body has been established to date, part of Professor Bonell's proposal did come to fruition with the establishment of both the Case Law on UNCITRAL Texts ("CLOUT") program and the UNCITRAL Digest. Correspondents from the member states collect and report annually on relevant CISG decisions from their jurisdictions. However, these two initiatives are limited to reporting decisions, not analyzing or commenting upon them. ${ }^{31}$

Success: 25 Years United Nations Convention on Contracts for the International Sale of Goods" (Collation of Papers at UNCITRAL - SIAC Conference 22-23 September 2005, Singapore); John E. Murray, The Neglect of CISG: A Workable Solution, 17 J.L. \& CoM. 365, 374 (1998). Albert Kritzer, of Pace University, and Loukas Mistelis, of Queen Mary, University of London, who assembled the original membership of the CISG Advisory Council, credit Bonell with first proposing the kind of body that eventually was realized in the form of the Advisory Council. Mistelis interview, supra note 14.

24. Michael Joachim Bonell, A Proposal for the Establishment of a "Permanent Editorial Board" for the Vienna Sales Convention, in UNIDROIT, INTERNATIONAL UNIFORM LAW IN PRACTICE 241(1988).

25. Id. at 243.

26. UNCITRAL, Report on the work of its $2 I^{\text {st }}$ Session, supra note 23, at 9 107-109.

27. Id.

28. $I d$.

29. The Secretariat note contrasts such a convention with the UNCITRAL Arbitration Rules and the UNCITRAL Conciliation Rules which have been adopted by the Commission, but are not part of the national laws of states. It states that "many of the objections to the performance of such a function with respect to conventions and model laws would not apply to the resolution of conflicting interpretations of these Rules." Dissemination of decisions concerning UNCITRAL legal texts and uniform interpretation of such texts: UNCITRAL, Note by the Secretariat, 16 UNCITRAL Y.B. 387 (1985) 389-90, U.N. Doc. A/CN.9/267, \10 (hereinafter "Dissemination").

30. Id.

31. See infra, notes 221-225 and accompanying text. 
Although UNCITRAL rejected the idea of an official advisory council, the need for a "follow up mechanism" to ensure uniform interpretation continued to trouble CISG commentators. In June 2001, a group of scholars met in Paris to discuss creating a CISG interpretive council. ${ }^{32}$ Albert Kritzer of Pace University and Loukas Mistelis of Queen Mary invited participants and convened the first meeting. The idea was that, by 2001 , a sufficient body of case law had emerged from national courts and arbitral tribunals to make the establishment of an interpretive council worthwhile. Kritzer and Mistelis invited a group of the most prominent CISG scholars, with an eye on balancing representation from different geographical regions and legal traditions. ${ }^{33}$

The idea was well received by those invited, and the "CISG Advisory Council" was established. ${ }^{34}$ Although it is not an official body, the Council functions much like one. Indeed, although it emphasizes that it is a private initiative, the Advisory Council has also taken on much of the appearance of an official body. For example, it drafted a "Charter" containing a preamble describing its mission, as well as articles specifying its procedures, membership, sponsors, and the roles of the chair and secretary. As will be discussed below, its opinions also read more like official commentaries than scholarly publications. However, the role of the Charter and the other quasi-official characteristics of the Advisory Council should not be exaggerated. The Charter remains only a Draft Charter as it was never signed by the CISG-AC members. As former Advisory Council Secretary Mistelis describes it, the group decided that enacting a formal charter would require it to incorporate in some jurisdiction and thereby lose its informal status. The Draft Charter functions as a "gentlemen's agreement," followed voluntarily in such matters as the appointment of new members and chairs, but is not formally binding. ${ }^{35}$

The Advisory Council's costs have been underwritten primarily through a variety of funds administered by the Pace University Institute of International Commercial Law and the Queen Mary Centre for Commercial Law Studies. ${ }^{36}$ However, the Advisory Council has also sought to procure funding from other sources and to schedule its meetings to coincide with academic conferences. For example, the Advisory Council meeting in Badenweiler, Germany, in May 2005 received funding from the Von Caemmerer Foundation, while the meeting in Wuhan, China in October 2007 was partly funded by the University of Wuhan. The November 2008 meeting, which took place in Tokyo, was funded in part by the Japanese government and by various Japanese foundations. As Japan has recently ratified the CISG, the Advisory Council meeting was intended to be part of a larger schedule of academic events and a campaign to

32. Mistelis, supra note 17 , at 454 .

33. Mistelis interview, supra note 14.

34. See Mistelis, supra note 17, at 454-55 for a list of the founding members.

35. Mistelis interview, supra note 14.

36. Id. 
promote the CISG in Japan. ${ }^{37}$

The CISG-AC's membership guidelines, as they are described in the Draft Charter, are straightforward: to become an Advisory Council member, one must be invited by at least two Council members and submit a curriculum vitae and letters of recommendation. ${ }^{38}$ Candidates may be elected by a simple majority ${ }^{39}$ to a five-year term, with two possible renewals. ${ }^{40}$ In order to limit costs and prevent discussion from becoming unmanageable, membership is capped at fifteen. ${ }^{41}$ The Council elects a chair and a secretary, who each serve three-year terms. $^{42}$ All members volunteer their time and receive no remuneration other than expenses incurred in the performance of their roles as members.

Although they do not formally represent their home or other countries, the Advisory Council Members inevitably bring to their discussions varied perspectives informed by the array of national, linguistic, and legal backgrounds from which they come. The mother tongues of past and current members include English, French, German, Italian, Japanese, Russian, Spanish, Greek, and Swedish. Four members may be described primarily as common law jurists ${ }^{43}$ and the other eight may be described as civil law jurists. ${ }^{44}$ The twelve current members of the Council are:

Professor Eric Bergsten (Chair),

Professor Michael Joachim Bonell,

Professor Michael Bridge,

Professor Alejandro Garro,

Professor Sir Roy Goode,

Professor John Gotanda,

Professor Sergei Lebedev,

Professor Jan Ramberg,

Professor Ingeborg Schwenzer,

Professor Hiroo Sono,

Professor Pilar Perales Viscasillas,

and Professor Claude Witz.

At the Advisory Council's meeting in Wuhan, China, in October 2007, Professor Bergsten was elected Chair and Professor Sieg Eiselen was elected its

37. Id.

38. CISG-AC Draft Charter art. II(3).

39. Id. at art. II(3).

40. Id. at art. II(1).

41. Id. at art. II(2).

42. Id. at arts. III(1), IV(1) \& (2).

43. These are Professors Bergsten, Bridge, Goode, and Gotanda.

44. These are Professors Bonell, Garro, Lebedev, Perales Viscasillas, Ramberg, Schwenzer, Sono, and Witz, 
second Secretary, replacing Professor Loukas Mistelis. All of the Council's current members have been members since its creation in 2001, except for Professors Perales Viscasillas and Schwenzer (members since 2003), Professor Gotanda (member since 2006) and Professor Bridge (member since 2007). Two of the founding members, Professor Allan Farnsworth and the first Chair, Professor Peter Schlechtriem, have passed away.

The Advisory Council members have predominantly academic backgrounds and experience, although some also perform significant work as arbitrators, expert witnesses, and counsel. Several current members are actively involved with UNCITRAL, most notably Professor Bergsten, former UNCITRAL Secretary and Chief of the International Trade Law Branch of the United Nations Office of Legal Affairs; national .UNCITRAL delegates Professors Bonell and Perales; and advisor to the Argentine delegation, Professor Garro. This academic orientation may prove to be both a strength and a weakness. Certain CISG-AC members may not take the same pragmatic approach to the CISG that a practitioner would take when advising clients or deciding CISG cases. Thus, the opinions may risk sounding overly scholarly or propose abstract solutions that are out of touch with the realities of CISG disputes. Indeed, former Secretary Mistelis reports that, at times, the CISG-AC has found itself divided between the more purely academic members and those with significant experience as practitioners. ${ }^{45}$ Since the founding of the Advisory Council, its opinions have become increasingly scholarly, in the sense of being written in a more academic style and being thoroughly footnoted. ${ }^{46}$ (Of course, this is largely due to the opinions becoming more comprehensively researched, which is hardly a fault).

Furthermore, although the current membership consists primarily of academics, this may change in the future, as the Draft Charter does not include any requirements as to the type of legal experience needed for membership. The original membership was also quite literally a senior group; nearly all of the founding members were over sixty years of age in 2001, and many were over seventy. The current membership is more mixed generationally, and includes members in their forties and fifties. The Advisory Council has also become more varied geographically, a trend which the members are eager to continue; they are particularly interested in adding members from Africa, China, and the Middle East.

The Advisory Council has also changed in that, initially, it was composed almost entirely of people who were present at the Vienna Conference where the CISG was created. A majority of the current members were not present at the CISG's drafting, which may lead to greater flexibility of interpretation: soon, no Advisory Council member's first-hand knowledge of the CISG drafters'

45. Mistelis interview, supra note 14.

46. A development recognized by the members. Id. 
intentions will trump other member's interpretations. ${ }^{47}$

\section{B. The Goal of Uniform Interpretation}

The Advisory Council's primary goal is to promote the uniform interpretation of the CISG by courts and tribunals. Uniformity is a core principle "which necessarily follows from the unificatory aim of the Convention." 48 To appreciate the Advisory Council's role in fostering uniformity, one must first understand the nature of the uniformity principle and the CISG's interpretive methodology.

CISG jurisprudence should not and, indeed, cannot be judged against a standard of absolute uniformity. The existence of multiple, equally authoritative linguistic versions of the CISG and the diversity of legal systems in which CISG disputes arise ensure that such an ideal is not achievable. However, absolute uniformity is not achieved even in domestic contexts, where the possibility of appeal to a single supreme court should, in theory, resolve all discrepancies in interpretation by the lower courts. Moreover, many legal rules include balancing tests or pockets of discretion designed to encourage judicial sensitivity to the equities of specific disputes. Different judges will also reach different conclusions on the meaning of even the most facially clear terms. For their part, appellate and supreme courts may be reluctant to second-guess discretionary decisions by lower courts and, in any event, cannot hear appeals on every case.

The CISG itself recognizes that absolute uniformity of interpretation is not achievable. To begin with, interpretive factors such as trade usages and the reasonableness standard - endemic to the CISG - preclude absolute uniformity. Moreover, there is good reason to believe that the CISG drafters never contemplated absolute uniformity as a goal; as DiMatteo, et al., point out, "The fact that Article 7 prefaces its uniformity mandate with 'regard is to be had' implies that a standard below strict uniformity in application was envisioned." 49 As a result, the standard by which CISG jurisprudence ought to be judged is one of relative or functional uniformity; that is, whether it reduces legal impediments to international trade.

The key to achieving uniformity is for national courts to follow the same methodology in interpreting the CISG. ${ }^{50}$ Article $7(1)$ of the CISG sets out the general rules for interpretation: "[i]n the interpretation of this Convention, regard is to be had to its international character and to the need to promote

47. Id. (confirming that there have been instances in CISG-AC discussions when Council members who participated in the Vienna Conference dismissed a proposed interpretation by stating that it had been considered and rejected by the CISG drafters).

48. Peter Schlechtriem, Article 7, in COMMENTARY ON THE UN CONVENTION ON THE INTERNATIONAL SALE OF GOODS (CISG) (Peter Schlechtriem \& Ingeborg Schwenzer, eds.) 97 (2d English ed. 2005).

49. DiMATTEO ET AL., supra note 1, at 11.

50. Id. at 19. 
uniformity in its application." This provision requires a judge to apply the CISG as "(a) international: [it] must be free from any influences (case law or legal theory) which are purely domestic; and (b) uniform: [it] must be congruent in its application at the international level to an extent that the internationality is respected." 51

These two interpretive principles yield two corresponding interpretive methodologies: first, courts must interpret the CISG in an "autonomous" manner, eliminating the influence of any domestic laws or modes of legal reasoning ${ }^{52}$ and second, courts and tribunals must ensure that their decisions conform to common international understandings of the CISG provisions at issue by considering decisions from courts in a variety of CISG signatory countries. ${ }^{53}$

This does not necessarily mean that all reference to domestic law is illegitimate. CISG article 7(2) provides:

Questions concerning matters governed by this Convention which are not expressly settled in it are to be settled in conformity with the general principles on which it is based or, in the absence of such principles, in conformity with the law applicable by virtue of the rules of private international law.

Thus, courts engage in what is called "gap-filling," 54 by turning to applicable domestic law if they cannot fill a gap in the CISG by reference to its general principles. ${ }^{55}$ Academic opinion is somewhat divided on what methodologies should be used, and in what order they should be applied, before

51. Andersen, supra note 10 , at 164 . See also Schlechtriem, supra note 48 , at 94.

52. BERNARD AUDIT, LA VENTE INTERNATIONALE DE MERCHANDISES 47 (1990); MARCO TORSELLO, COMMON FEATURES OF UNIFORM COMMERCIAL LAW CONVENTIONS: A COMPARATIVE STUDY BEYOND THE 1980 UNIFORM SALES LAW 18 (2004); Ferrari, supra note 10, at 234; JOHN O. HONNOLD, UNIFORM LAW FOR INTERNATIONAL SALES UNDER THE UNITED NATIONS CONVENTION 47 (3d ed.,1999). Of course, this principle applies to the interpretation of all uniform laws. For example, Briggs writes that the 1980 Rome Convention on the Law Applicable to Contractual Obligations, which governs choice of law in contract disputes decided in European Union courts, must "receive an independent or autonomous interpretation, and will not be read as if they were pieces of domestic .. legislation." BRIGGS, supra note 12, at 150 . On the autonomous interpretation of international documents generally, see ZWEIGERT \& KöTZ, supra note 15, at 21.

53. Gyula Eörsi, who was president of the diplomatic conference at which the CISG was promulgated, confirms that the two interpretive principles set out in article $7(1)$ were drafted to achieve this specific result: "The first ... was devised to check the homeward trend, and the second is an admonition to follow precedents on the international plane." Gyula Eörsi, General Provisions, in INTERnAtional SALES: THE UNITED NATIONS CONVENTION ON CONTRACTS FOR THE INTERNATIONAL SALE OF GOODS $\S 2.03$ (Nina M. Galston \& Hans Smit eds., 1984).

54. This frequently-used phrase refers to the resolution of issues which either are not governed by the CISG ("external gaps") or which are governed by the CISG but not expressly settled in it ("internal gaps," with which article 7(2) is concerned). See Schlechtriem, supra note 48, at 102-09; Alejandro M. Garro, The Gap-Filling Role of the UNIDROIT Principles in International Sales Law: Some Comments on the Interplay between the Principles and the CISG, 69 TUL. L. REV. 1149 (1995).

55. Schlechtriem therefore describes reference to domestic law as a "last resort." Schlechtriem, supra note 48, at 109. 
a court turns to domestic law, but all agree that it can be referred to as a last resort. 56

Much of the commentary on Article 7 places particular emphasis on the need for adjudicators to consult the decisions of foreign courts. ${ }^{57}$ CISG-AC member Claude Witz states that a central goal of his book on the jurisprudence of the CISG is to inculcate in adjudicators the practice of considering precedents from every signatory state. ${ }^{58}$ Indeed, while the CISG does not itself impose any obligation on courts or tribunals to refer to foreign case law, ${ }^{59}$ many consider this to be a "duty" of courts deciding disputes under the CISG. ${ }^{60}$

56. The disagreement lies between those who believe that the CISG's general principles should be the first recourse to filling a gap or explaining an ambiguity in the text of the CISG, those who believe that the first step should be to reason analogically from other CISG provisions, and those who believe that these two techniques ought to be used in parallel and that neither should take precedence. There is a general consensus that recourse to domestic law is the final step, legitimate only if the other techniques do not provide a workable solution. See generally Anna Kasimierska, The Remedy of Avoidance under the Vienna Convention on Contracts for the International Sale of Goods, PACE INT'L L. REV., REVIEW OF THE CONVENTION ON CONTRACTS FOR THE INTERNATIONAL SALE OF GOODS: 1999-2000, 79, 172 (2000) (arguing that the two methodologies of resort to general principles and reasoning by analogy to other CISG provisions should be applied non-hierarchically).

57. See, e.g., Ferrari, supra note 10, at 234; Joseph Lookofsky, Digesting CISG Case Law: How Much Regard Should We Have?, 8 V. J. INT'L COM. L. \& ARB. 181, 184 (2004); Philip Hackney, Is the United Nations Convention on the International Sale of Goods Achieving Uniformity?, 61 LA. L. REV. 473, 479 (2001); Bruno Zeller, The UN Convention on Contracts for the International Sale of Goods: A Leap Forward Towards Unified International Sales Laws, 12 PACE INT'L L. REV. 79, 104 (2000); J.M. Darkey, A U.S. Court's Interpretation of Damage Provisions Under the U.N. Convention on Contracts for the International Sale of Goods: A Preliminary Step Towards an International Jurisprudence of CISG or a Missed Opportunity, 15 J.L. \& COM. 139, 142 (1995); H. Elizabeth Hartnell, Rousing the Sleeping Dog: The Validity Exception to the Convention on Contracts for the International Sale of Goods, 18 YALE J. INT'L L. 1, 45-50 (1993); Kuzuaki Sono, The Vienna Sales Convention: History and Perspective, in INTERNATIONAL SALE OF Goods: Dubrovnik Lectures 8 (Peter Šarčević \& Paul Volken, eds., 1986); Franco Ferrari, International Sales Law and the Inevitability of Forum Shopping: A Comment on Tribunale Di Rimini, 23 J.L. \& CoM. 169, 172 (2004).

58. Vivian Grosswald Curran, The Interpretive Challenge to Uniformity, 15 J.L. \& CoM. 175, 179 (1995) (quoting CLAUDE WITZ, LES PREMIERES APPLICATIONS JURISPRUDENTIELLES DU DROIT UNIFORME DE LA VENTE INTERNATIONALE 15 (1995)).

59. Andersen, supra note 10 , at 167.

60. Camilla Baasch Andersen, Reasonable Time in Article 39(1) of the CISG-Is Article 39(1) Truly a Uniform Provision?, in PACE REVIEW OF THE CONVENTION ON CONTRACTS FOR THE INTERNATIONAL SALE OF GOODS 72 (1998). See also Rogers \& Kritzer, supra note 5, at 226. This principle does not apply just to the CISG. In general, this principle applies when interpreting international conventions and uniform law instruments that have been incorporated into domestic law. Indeed, courts should be "obliged to ... take into consideration foreign judgments and doctrine ... when [they are] faced with a problem of interpretation of an international convention." Leif Sevón, Observations, in UNIDROIT, INTERNATIONAL UNIFORM LAW IN PRACTICE [Acts and Proceedings of the 3rd Congress on Private Law held by the International Institute for the Unification of Private Law (Rome 7-10 September 1987)] 135 (1988). The English House of Lords has confirmed this point of view, holding that, when interpreting international conventions, courts should "develop their jurisprudence in company with the courts of other countries from case to case." Fothergill v. Monarch Airlines, 1981 A.C. 251 (Eng. H.L.); [1980] 2 All E.R. 696, at p. 715 (speech of Lord Scarman). 
However, as to the precedential status of a foreign court or arbitral tribunal's decision, no single, accepted scale or rubric exists. While some have referred to the consultation of foreign precedents as an "informal supranational stare decisis," 61 a formulation that may indicate the existence of binding precedents, ${ }^{62}$ foreign decisions can only have persuasive value. National courts have thus far unanimously adopted the latter position. ${ }^{63}$

The degree of persuasiveness will vary. Lookofsky cites a (nonexhaustive) list of factors that might influence a court in assessing a decision's persuasiveness: the force of reasoning of the foreign opinion, the apparent soundness of the result, the rank of the foreign court that issued the opinion, and whether the opinion is consistent with the general rule in the jurisdiction of the court that issued it. ${ }^{64}$ In this vein, arbitral awards interpreting the CISG may carry more weight than the opinions of foreign judges, due to the neutral, stateless nature of arbitral tribunals and the fact that they deal primarily with transnational disputes, and so may have particular expertise in the area. ${ }^{65}$

Despite the scholarly focus on case law, a court's inquiry must "recognize

61. Larry A. DiMatteo, The CISG and the Presumption of Enforceability: Unintended Contractual Liability in International Business Dealings, 22 YALE J. INT'L L. 111, 133 (1997).

62. Franco Ferrari, Ten Years of the U.N. Convention: CISG Case Law - A New Challenge for Interpreters?, 17 J.L. \& Com. 245, 259 (1998). DiMatteo rejects this characterization. DiMatteo, supra note 61 , at $132-33$.

63. See UNCITRAL, UNCITRAL Digest of case law on the United Nations Convention on the International Sale of Goods, of 4, U.N. Doc. A/CN.9/SER.C/DIGEST/CISG/7 (June 8 2004), available at http://daccessdds.un.org/doc/UNDOC/GEN/V04/547/56/PDF/V0454756. The UNCITRAL Digest cites three Italian cases to this effect: CLOUT case No. 378 [Tribunale di Vigevano, Italy, 12 July 2000]; CLOUT case No. 380 [Tribunale di Pavia, Italy, 29 December 1999]; Trib. Rimini, Italy, 26 November 2002, Giurisprudenza italiana, 2003, $896 \mathrm{ff}$. See also Chicago Prime Packers, Inc. v. Northam Food Trading Co., et al., 320 F. Supp. 2d 702, 709 (N.D. Ill. 2004) (stating that "although foreign case law is not binding on this court, it is nonetheless instructive in deciding the issues presented here"). This is also the majority view among commentators. See, e.g., Ferrari, supra note 10, at 250 and the articles cited in n. 123; Peter Schlechtriem, Uniform Sales Law - the Experience with Uniform Sales laws in the Federal Republic of Germany, in 2 JURIDISK TIDSKRIFT 1, 14 (1991/92) (The purpose of the UNCITRAL Digest is to "facilitate the functioning of judicial decisions if not as precedent, as persuasive authority for . . . courts in other countries"); Andersen, supra note 10, at 167. For the contrary view (i.e. that foreign cases should have the weight of precedent "[i]f there is already a body of international case law"), see M. J. Bonell, Article 7, in COMMENTARY ON THE INTERNATIONAL SALES LAW : THE 1980 VIENNA SALES CONVENTION 91 (C. M. Bianca \& M. J. Bonell eds., 1987); DiMatteo, supra note 61, at 132-3 (advocating a "supranational stare decisis"-a phrase that seems especially to irk many of the majority opinion).

64. Lookofsky, supra note 57, at 187 (citing E. ALLAN FARNSWORTH, AN INTRODUCTION TO THE LEGAL SYSTEM OF THE UNITED STATES 52-57 (3d ed. 1996).

65. In addition, members of international arbitral tribunals are often selected because they have special authority or expertise relevant to a dispute (the better to sway the other members of the tribunal, a cynic might say). Thus, arbitrators deciding a dispute whose governing law is the CISG are more likely to have experience with the CISG than are national court judges. Ferrari champions this viewpoint, arguing that "an arbitral award could have more influence on a specific situation than a decision of a supreme court of a country whose judges are not accustomed to dealing with international issues in general, and the CISG in particular." Ferrari, supra note 62, at 260. 
that the method of interpretation still remains a textual one, with the addition that the purpose of the Convention, the legislative history, and the drafters' intent may be taken into account." 66 Thus, according to the CISG's own interpretive guidelines, a court should begin with the plain meaning of a given CISG provision, placed in the context of its purpose and legislative history. Only if this fails to yield a clear resolution should the court consider the CISG's underlying principles, analogize to other CISG provisions, and take into account precedents from its own or other countries. If all else fails, the court may consider its domestic law.

While reference to the legislative history of a disputed CISG provision is indisputably legitimate, it does have its dangers. The travaux préparatoires of international conventions are not necessarily as useful as those of domestic legislation - there are too many delegates from too many countries, too many proposals and counter-proposals, and too much horse-trading as opposed to actual consensus-so that these travaux tend to be least helpful in the controversial areas where they are most needed. ${ }^{67}$ Such drawbacks have led various scholars to caution adjudicators against dependence on the CISG's legislative history. For example, Ferrari warns that "recourse to such materials must not be overestimated." 68 Even Honnold, who compiled the most-cited source of CISG legislative history, ${ }^{69}$ counsels tribunals to limit reliance on travaux to the generalities. ${ }^{70}$

In addition, courts adjudicating CISG disputes-even in common law countries-frequently cite scholarly commentaries on the Convention. Indeed, the direction in Article 7(2) that "[q]uestions concerning matters governed by this Convention which are not expressly settled in it are to be settled in conformity with the general principles on which it is based" practically demands the judge to consult doctrinal writings. ${ }^{71}$ After all, the elucidation of the principles underlying legislation is one of the central roles of scholars. In this way, as Curran argues, the CISG guides jurists-at least with respect to gapfilling - toward a methodology typical of that used in the interpretation of civil codes, wherein the language of a canonical text is interpreted according to the

66. Zeller, supra note 57, at 89. See also Schlechtriem, supra note 48, at 101.

67. Lookofsky and Hertz point to the U.S. Supreme Court's decision in Volkswagenwerk A.G. v. Schlunk, 486 U.S. 694 (1988), where both the majority and minority opinions referred to excerpts from the same legislative history (of the Hague Service Convention) in support of mutually exclusive positions. JOSEPH M. LOOKOFSKY \& KETILBJøRN HERTZ, TRANSNATIONAL LITIGATION AND COMMERCIAL ARBITRATION: AN ANALYSIS OF AMERICAN, EUROPEAN AND INTERNATIONAL LAW Ch. 42 (2d ed. 2004). See also Aneta Spaic, Approaching Uniformity in International Sales Law through Autonomous Interpretation, 11 V. J. INT'L COM. L. \& ARB. 237, 256 (2007).

68. Ferrari, supra note 3, at 206.

69. HONNOLD, DOCUMENTARY HISTORY, supra note 3 (written as a personal documentary history of the CISG).

70. HONNOLD, supra note 52, at 463.

71. CISG art. 7(2) (emphasis added). 
writings of prominent scholars. ${ }^{72}$

Finally, courts and tribunals may refer to the comprehensive Secretariat Commentary to the 1978 Draft of the CISG. However, as its name suggests, the Secretariat Commentary was prepared by the UNCITRAL Secretariat, based on a draft of the Convention prepared by the same body. It is not an official commentary, as it was never approved by the diplomatic conference that negotiated the final version of the CISG. In addition, it was never updated to reflect the final text of the CISG, and important differences exist between the 1978 draft and the CISG as enacted. ${ }^{73}$ Finally, the Secretariat Commentary's interpretations have been criticized in a number of respects. ${ }^{74}$ Despite these drawbacks, it is frequently cited erroneously as an official commentary. ${ }^{75}$

\section{The Drafting of Opinions}

Although a private body, the Advisory Council functions much like an official council. Indeed, it is much more institutionalized than one might expect from an informal group of academics. The Draft Charter lays out procedures, reflecting the desire to operate in an official manner, for the writing of opinions: although, as noted above, the Charter was never signed, the Advisory Council appears to have continued to follow these procedures. ${ }^{76}$

The topic for an opinion may be suggested by a member or come via requests from international organizations, counsel, professional associations, or adjudicative bodies. ${ }^{77}$ The Draft Charter, however, states that requests may be made "in particular" by these bodies, thus implying that there is no restriction on who may submit requests for opinions. ${ }^{78}$ However, the Advisory Council considers requests only from institutions, not from individuals. It has received several requests for opinions from litigants seeking, in effect, expert opinions for use in litigation. However, it has declined these requests on the grounds that it is not a private consultative body, that many of its members act individually as consultants and expert witnesses, and that such engagements by the Advisory Council itself might compromise the academic freedom and integrity of its

72. Curran, supra note 58 , at 177.

73. CISG provisions that either did not exist in or were substantially modified after the 1978 draft include arts. 5, 7(2), 13, 19, 25, 44, 46(3), and 80 .

74. See, e.g., Disa Sim, The Scope and Application of Good Faith in the Vienna Convention on Contracts for the International Sale of Goods, 19, 21, in REVIEW OF THE CONVENTION ON CONTRACTS FOR THE INTERNATIONAL SALE OF GOODS 2002-2003, 21 (Pace Int'l L. Rev. ed., 2004). (finding the Secretariat Commentary to Article 7 unclear and not the "most appropriate interpretation").

75. Murray, supra note 23, at 377 (citing various decisions and academic articles that refer to the Secretariat Commentary as "official comments").

76. Mistelis interview, supra note 14.

77. CISG-AC Charter art. I(3).

78. Id. 
individual members. ${ }^{79}$

If it receives a request, the Advisory Council is not obligated to issue an opinion. 80 Since there are always more topics worthy of discussion than time available, the CISG-AC must prioritize. In practice, it tends to choose issues of broad interest that have some element of urgency (generally, where significant diversity of opinion among national courts has arisen). ${ }^{81}$

Once the Council decides to render an opinion regarding a particular issue, it selects a rapporteur who will research the question and draft a report. The rapporteur, who may or may not be a member of the CISG-AC, is generally a scholar somewhat younger than the bulk of the CISG-AC membership who has specific expertise in the aspect of CISG doctrine at issue. Of the nine published opinions, two were initially prepared by rapporteurs who were not Council members. Christina Ramberg, a practicing lawyer and professor with expertise in electronic commerce (and also the daughter of former Advisory Council Chair Professor Jan Ramberg), prepared the first opinion on electronic communications under the CISG. Richard Hyland, an American professor, was the rapporteur for the third opinion on the parol evidence and plain meaning rules.

While rapporteurs should not simply advocate their personal opinions, they must necessarily recommend an answer to the question posed or an interpretation of the CISG article at issue. ${ }^{82}$ The rapporteur continues to be involved throughout the deliberation process by taking note of the Council members' views and then drafting the final opinion. In practice, the rapporteur's initial report is often informally discussed by the rapporteur, the Chair, and CISG-AC founder Albert Kritzer before being presented to the Advisory Council as a whole. After the rapporteur presents the report, the Council agrees on the text of the "blackletter section" of the opinion, which states in concise terms and legislative style the core of the Advisory Council's interpretation. After the blackletter is approved, the rapporteur goes on to draft the remainder of the opinion. ${ }^{83}$ The Council then edits, refines, and approves the draft; however, much less editing is done on the comments that form the bulk of the opinion than on the blackletter, giving the rapporteur a fair amount of discretion. The Secretary is often tasked with redrafting the final text as necessary to make the style uniform so that it does not read like the work of a committee. ${ }^{84}$

The Advisory Council Chair also plays a key part in the preparation of

79. Mistelis interview, supra note 14. The Advisory Council has discussed the possibility of submitting an amicus curiae brief in a relevant litigation, but a good opportunity to do so has not yet presented itself. $I d$.

80. CISG-AC Charter art. I(4).

81. Mistelis interview, supra note 14.

82. Mistelis likens this process to a doctoral student defending his or her thesis. Id.

83. Id.

84. Id. 
opinions. Once a report is ready for discussion, the Chair convenes a meeting, prepares an agenda, and presides over the deliberations. ${ }^{85}$ Former Chair Jan Ramberg described the "pattern . . . [of] friendly spirit of cooperation" during deliberations established by the first Chair, Peter Schlechtriem. ${ }^{86}$ Although Council members may express differing views, ultimately they attempt to reach a unanimous decision, and the Chair assists them in doing so. ${ }^{87}$ The first nine opinions were adopted without dissent, but the Advisory Council has, on occasion, struggled to reach a consensus. ${ }^{88}$ Nevertheless, only a two-thirds majority is needed to adopt an opinion and dissenting views will be published. ${ }^{89}$ Unanimity may not be necessary, but the CISG-AC members believe that it strengthens the positions adopted in an opinion and ultimately the status of the Council. ${ }^{90}$

\section{The CISG Advisory Council Compared}

The Advisory Council may be compared to a number of other institutions that have undertaken similar tasks or function in similar ways. First, as its name indicates, the Advisory Council is a council, not a court. A number of supranational courts render advisory opinions regarding the proper interpretation of international conventions and laws. The most obvious example may be the European Court of Justice, which is the final court of appeal for European Community matters; its decisions are binding on the legislatures and courts of member states. ${ }^{91}$ Some international courts, including the International Court of Justice, ${ }^{92}$ the Inter-American Court of Human Rights, ${ }^{93}$ the European Court of Human Rights, ${ }^{94}$ and the African Court of Human and People's Rights, ${ }^{95}$

85. CISG-AC Charter art. III(2).

86. Interview by Fan Yang with Professor Jan Ramberg, CISG-Advisory Council, in Philadelphia, Pa. (Nov. 2005), available at http://www.cisgac.com/default.php?ipkCat=129\&ifkCat $=136 \&$ sid $=163$ [hereinafter Ramberg interview].

87. Id.

88. Mistelis interview, supra note 14.

89. Id.

90. See Ramberg interview, supra note 86 ("Although each member has a right to submit his or her dissenting opinion, it would erode the authority of the Council and the value of the opinions, if there were one or more dissenting opinions.").

91. Under article $\mathbf{1 7 7}$ of the Treaty Establishing the European Economic Community, national courts may ask the European Court of Justice to render a preliminary ruling. Treaty Establishing the European Economic Community, Mar. 25, 1957, 1992 O.J. (C224/1) [hereinafter EEC Treaty].

92. The International Court of Justice may be asked to render "an advisory opinion on legal questions." Julie Caldonio Schmid, Advisory Opinions on Human Rights: Moving Beyond a Pyrrhic Victory, 16 DUKE J. COMP. \& INT'L L. 415,418 (2006).

93. The IAHCR may render opinions regarding the interpretation of the American Convention. Organization of American States, American Convention on Human Rights, art. 64, Nov. 22, 1969, O.A.S.T.S. No. 36, 1144 U.N.T.S. 123.

94. The European Court of Human Rights can issue opinions regarding "legal questions concerning the interpretation of the Convention." See European Convention for the Protection of 
render non-binding advisory opinions. The Benelux Court of Justice also renders non-binding opinions regarding the interpretation of legal rules common to Belgium, the Netherlands, and Luxembourg. While some have called for the creation of an international CISG court with appellate authority, ${ }^{96}$ UNCITRAL indirectly rejected this proposal and most agree that, even though it might be beneficial, it is politically impossible. ${ }^{97}$

In debating whether to establish an official advisory body, UNCITRAL also considered the example of two bodies in the International Monetary Fund (IMF) system. ${ }^{98}$ The IMF Executive Directors may be asked to provide guidance as to the interpretation of the Articles of Agreement between IMF members or between a member and the IMF. ${ }^{99}$ Their decision can be referred (appealed, essentially) to the Board of Governors, whose decision is final. ${ }^{100}$ Like the Advisory Council, these bodies interpret international conventions and uniform laws and seek to achieve uniformity of application. The IMF entities have, however, been empowered to provide such interpretations by the states which are parties to or which have ratified those conventions. The lack of such explicit authorization by its member states was the primary reason UNCITRAL declined to establish an interpretive body under its own auspices. ${ }^{101}$

Human Rights and Fundamental Freedoms, art. 47, Nov. 4, 1950, 213 U.N.T.S. 222.

95. The African Court of Human's and People's Rights may issue advisory opinions on "any legal matter relating to the Charter or any other relevant human rights instrument." Protocol to the African Charter on Human's and People's Rights on the Establishment of an African Court on Human and People's Rights, art. 4.

96. See, e.g., Sim, supra note 74 , at 21 ("an intemational commercial court ... would help to minimize the likelihood of incoherence and multiple contradictory determinations"); Christopher Sheaffer, Note, The Failure of the United Nations Convention on Contracts for the International Sale of Goods and a Proposal for a New Uniform Global Code in International Sales Law, 15 CARDOZO J. INT'L \& COMP. L. 461, 483 (2007) (calling for creation of a Global Code and of an international court that would develop "a unified system to add consistency in the interpretation [of the code]").

97. Dissemination, supra note 29 , at $389-90$ (stating that this would "involve [UNCITRAL] in intervening in interpretations by courts of their own national laws when the competence to do so has not been granted to [it]'); M.J. Bonell, Interpretation of Convention, in COMMENTARY ON THE InTERnational SALES LaW, THE 1980 Vienna SAles Convention 89 (C.M. Bianca \& M.J. Bonell, eds., 1987) ("To expect that all adhering states, notwithstanding their different social, political and legal structure, could even agree on conferring to an international tribunal the exclusive competence to resolve divergences between the national jurisdictions in the interpretation of the uniform rules, would be entirely unrealistic.").

98. Dissemination, supra note 29 , at $389-90$ (referencing the Commission on Banking Technique and Practice of the International Chamber of Commerce ("ICC") which drafts opinions regarding queries on the Uniform Customs and Practice for Documentary Credits from banks, ICC national committees and other institutions).

99. INTERNATIONAL MONETARY Fund, ARTICLES OF AGREEMENT OF THE INTERNATIONAL MONETARY FUND 56 (1993), available at $\mathrm{http}: / / \mathrm{www} . i m f . o r g / e x t e r n a l / p u b s / \mathrm{ft} / \mathrm{aa} / \mathrm{aa} . \mathrm{pdf}$.

100. Id.

101. Dissemination, supra note 29 , at 389-90 (stating that " $[\mathrm{t}]$ hese procedures may therefore not be viewed as precedents for the assumption by the Commission of competence to interpret legal texts which have been incorporated into the national law of States."). 
Although the comparison is not exact, the Advisory Council has been likened to two "private legislatures" 102 in the United States: the Uniform Law Commission ("ULC," which was until 2007 called the National Conference of Commissioners of Uniform State Laws) and the American Law Institute ("ALI"). Created in 1892, the ULC prepares uniform and model laws in a wide range of civil and commercial areas and in criminal procedure. ${ }^{103}$ Composed of representatives appointed by the states, the District of Columbia, and certain U.S. territories, it meets annually to discuss drafts of proposed legislation and reports on pending projects. ${ }^{104}$ The ALI, on the other hand, was founded in 1923 to address uncertainty in the law through the drafting of comprehensive summaries of various areas of law which would provide guidance to judges and practitioners. ${ }^{105}$ Today, the ALI includes some 3,000 members and its "Restatements" cover most areas of law. Both the ALI and ULC exist outside of governmental control, although ULC members are appointed by the U.S. state and territorial governments. Collaboration between the two organizations produced the Uniform Commercial Code (UCC).

Like the ALI and the ULC, the Advisory Council seeks to achieve uniformity and clarity in the law. However, its scope of mission and membership are entirely different. Unlike the ALI and the ULC, the Advisory Council focuses solely on one international convention, the CISG, and renders opinions on specific controversial topics; it does not draft domestic model laws like the ULC, nor does it provide comprehensive commentaries on entire areas of law like the ALI. In this sense, the closest equivalent to the two American bodies with respect to the CISG is UNCITRAL. Finally, the CISG-AC's membership consists of a small circle of eminent scholars, while the ALI and ULC include academics, judges, practitioners, civil servants, and occasionally politicians.

The Advisory Council is most analogous to the UCC Permanent Editorial Board, which was the model for Bonell's proposal for a permanent CISG Editorial Board. ${ }^{106}$ Since 1987, this joint committee of the ULC and ALI has examined problems in the judicial treatment of UCC provisions and issued supplemental commentary on those provisions. ${ }^{107}$ With only twelve members

102. Paul B. Stephan, The Futility of Unification and Harmonization in International Commercial Law, 39 VA. J. INT'L L. 743, 757 (1999) (citing Robert E. Scott, The Politics of Article 9, 80 VA L. REV. 1783 (1994)).

103. Frederick H. Miller, Patricia B. Fry \& John P. Burton, Introduction to Uniform Commercial Code Annual Survey: The Centennial of the National Conference of Commissioners on Uniform State Laws, 46. BUS. LAW. 1449, 1451 (1991).

104. See Uniform Law Commission, National Conference of Commissioners on Uniform Law States, http://www.nccusl.org/Update/DesktopDefault.aspx?tabindex $=0 \&$ tabid=11 (last visited Mar. 14, 2009).

105. For further information regarding the ALI, see American Law Institute, http://www.ali.org/index.cfm?fuseaction=about.instituteprojects (last visited May 14, 2008).

106. See supra notes 23-25 and accompanying text.

107. Id. at 1452. 
from various American states, its membership more closely resembles that of the Advisory Council. ${ }^{108}$ The UCC Permanent Editorial Board also assists in promoting uniformity by discouraging non-uniform amendments to the UCC by the states, and by approving and promulgating amendments to the UCC when necessary. ${ }^{109}$ (Of course, amendments to the UCC itself do not change any laws - states would have to enact the amendments into their own versions of the UCC; however, amendments proposed by the Editorial Board are typically adopted by the states.) $)^{110}$ While the Advisory Council does not work with a model law and certainly does not have the power to amend the CISG, it monitors divergent applications and could, conceivably call for amendments to the CISG.

III.

\section{THE IMPACT OF THE ADVISORY COUNCIL ON THE} UNIFORM INTERPRETATION OF THE CISG

In this section, we consider what impact the Advisory Council has had on the development of CISG doctrine. In order to place the Advisory Council's actions in context, we first consider the current state of CISG jurisprudence. While a comprehensive survey of CISG jurisprudence from around the world is beyond the scope of this article, it is the subject of avid commentary from a variety of CISG scholars. Perhaps the best-known national court decision applying the CISG is that of the Italian Tribunale di Vigevano rendered on July 12,2000 , which referred to an unprecedented (and still unequalled) forty foreign court decisions. ${ }^{111}$ However, civilian courts' adherence to correct CISG interpretive methodology has by no means been consistent; a substantial number of courts continue to exhibit a homeward trend in their interpretations of the

108. It should be noted, however, that the UCC Permanent Editorial Board is composed of practitioners as well as academics. For a list of the board's members, see American Law Institute, Permanent Editorial Board for the UCC, http://www.ali.org/index.cfm?fuseaction=projects.members \&projectid=4 (last visited Aug. 27, 2008).

109. See http://www.ali.org/index.cfm?fuseaction,=projects.proj_ip\&projectid=4 (last visited May 14, 2008).

110. At least, this was so until the most recent round of proposed amendments to UCC articles 1 and 2, which have met with significant opposition. See, e.g., James J. White, Out with the Old, In with the New? Articles 2 and $2 A$ of the Uniform Commercial Code, 3 DePAUL Bus. \& COM. L.J. 519 (2005) (calling the most recent set of proposed amendments a "failed statute" and likening the revised article 2 to "the proverbial goose that flew in ever concentric circles, or ever decreasing radius until it flew up its own ass and disappeared with a loud metallic clap.").

111. The Vigevano court cited decisions from Austria, France, Germany, the Netherlands, Switzerland, and the United States. The decision has been discussed at length (and much praised) by a variety of commentators. See, e.g., Francesco G. Mazzotta, The International Character of the UN Convention on Contracts for the International Sale of Goods: An Italian Case Example, 15 PACE INT'L L. REV. 437 (2003); Franco Ferrari, Tribunale di Vigevano: Specific Aspects of the CISG Uniformly Dealt With, 20 J.L. \& COM. 225 (2001). 
CISG and to decline to consult foreign decisions and arbitral awards. ${ }^{112}$

Much of the attention on case law developments has focused on the U.S., ${ }^{113}$ where courts have traditionally been more reluctant to embrace the kind of internationalism exemplified by the Tribunale di Vigevano decision. ${ }^{114}$ More recently, however, U.S. courts have been increasingly willing to follow the CISG's interpretive methodology. The leading case today is MCC-Marble Ceramic Center, Inc. v. Ceramica Nuova d'Agostino, S.p.A., in which the U.S. Court of Appeals for the Eleventh Circuit eschewed American rules precluding admission of parol evidence and interpreted the CISG autonomously, holding that it requires the admissibility of such evidence. ${ }^{115}$ In doing so, it examined foreign case law and scholarly commentaries on the CISG, both for guidance on the CISG's interpretive methodology and for the specific point at issue. ${ }^{116}$ U.S. courts since MCC-Marble have for the most part followed its lead. ${ }^{117}$

As CISG precedents have piled up, courts have displayed an increasing willingness to interpret the convention autonomously and to consult international opinion in the form of foreign case law. As DiMatteo, et al. conclude, "Although it has not yet attained critical mass, CISG jurisprudence has grown significantly. As it has grown, greater uniformity of application has been evidenced." 118 Nevertheless, particularly in "areas, such as the battle of forms, [which] are particularly subject to homeward trend interpretations," considerable diversity of opinion persists. ${ }^{119}$

We consider below the Advisory Council's impact on the promotion of the

112. See, e.g., Italdecor SAS v. Yiu's Industries (H.K.) Ltd., Corte app. di Milano [Regional Court of Appeals], Mar. 20, 1998 (It.) available at http://cisgw3.law.pace.edu/cases/980320i3.html (finding that the CISG applied, but then improperly reasoning from domestic law).

113. This is due in large part to the U.S.'s economic importance, and to the apparent antipathy of American judges to foreign laws and courts. However, it is also important to remember that the United Kingdom has not ratified the CISG, so there is no UK case law on it. On the CISG in the UK, see Anna Rogowska, CISG in UK: How does the CISG govern the contractual relations of English businessmen?, 18(7) INT'L CO. \& COM. L. REV. 226 (2007). On the UK's failure to ratify the CISG, see Sally Moss, Why the U.K. Has Not Ratified the CISG, 25 J. L. \& COM., 483 (2005).

114. An oft-cited example is Filanto S.p.A. v. Chilewich Int'l Corp., 789 F. Supp. 1229, 1237 (S.D.N.Y. 1992), in which the court lamented the fact that "the Uniform Commercial Code . . does not apply to this case, because the State Department undertook to fix something that was not broken by helping to create the Sale of Goods Convention, which varies from the Uniform Commercial Code in many significant ways."

115. MCC-Marbel Ceramic Ctr. v. Ceramica Nuova d'Agostino, S.p.A, 144 F.3d 1384 (11th Cir. 1998).

116. Conducting its own search, the court found no foreign cases discussing the admissibility of parol evidence under the CISG. It therefore turned to various academic writings on the subject. Id. at $1389-91$.

117. See, e.g., St. Paul Ins. Co. v. Neuromed Med. Sys., No. 00 Civ. 9344(SHS), 2002 U.S. Dist. LEXIS 5096 (S.D.N.Y. Mar. 26, 2002).

118. DiMATTEO ET AL., supra note 1 , at 163.

119. Id. at 174 . 
CISG's uniform interpretation. We describe the opinions that the Advisory Council has thus far submitted (A) and assess the legal status of these documents (B). We then examine the reception of the Advisory Council's opinions, both by adjudicators (C) and by the academic community (D).

\section{A. The Opinions of the Advisory Council}

Here, we examine the Advisory Council opinions themselves: their content, structure, style, and use of legal sources. As discussed above, the opinions have been the result of outside requests as well as of the Council's own initiative. They consistently read much like an official commentary to the CISG, with only minor variations in style and format. From August 2003 to May 2009, the Advisory Council issued nine opinions:

Opinion 1: Electronic Communications under the CISG

Opinion 2: Examination of the Goods and Notice of Non-Conformity Articles 38 and 39

Opinion 3: Parol Evidence Rule, Plain Meaning Rule, Contractual Merger Clause and the CISG

Opinion 4: Contracts for the Sale of Goods to Be Manufactured or Produced and Mixed Contracts (Article 3 CISG)

Opinion 5: The Buyer's Right to Avoid the Contract in Case of NonConforming Goods or Documents

Opinion 6: Calculation of Damages under CISG Article 74

Opinion 7: Exemption of Liability for Damages Under Article 79 of the CISG

Opinion 8: Calculation of Damages under CISG Articles 75 and 86

Opinion 9: Consequences of Avoidance of the Contract

Of the nine opinions, five have resulted from outside requests. The bodies that submitted requests for guidance and whose requests have given rise to opinions are the International Chamber of Commerce (Opinion No. 1), both the Utrecht Working Group on Sales Law of the Study Group on a European Civil Code (Opinion No. 2) and the Steering Committee of the Study Group on a European Civil Code (Opinion No. 4), ${ }^{120}$ as well as the Association of the Bar of the City of New York Committee on Foreign and Comparative Law (Opinion No. 3) and the International Sales Committee of the International Law and Practice Section of the New York State Bar Association (Opinion No. 5). The sixth through ninth opinions were prepared at the Advisory Council's own initiative.

Nothing in the Draft Charter or opinions indicates how many requests the CISG-AC has received to date or what factors lead the Advisory Council to render an opinion on a given issue. Certain opinions, however, seem oriented

120. Advisory Council member Roy Goode is a member of the Steering Committee. 
towards a specific audience within the international sales law community. For instance, the third opinion-issued in response to a request from an American body, the City Bar of New York-addresses an issue that has been a source of confusion and divergent applications in the United States and other common law countries: the relationship between the parol evidence and plain meaning rules and the CISG. Civil law has no rules analogous to these doctrines, and the opinion is likely to be of only academic interest in civil law jurisdictions. However, most of the opinions relate to issues of global significance. For example, the question of timely examination and notice of non-conformity under the CISG has been of concern to a number of common and civil law jurisdictions and is the subject of a well-developed body of case law in Germany.

The structure and style of the opinions has evolved somewhat since the first opinion. The more recent opinions are all divided into two sections: "opinion" and "comments." The opinion section, which some Advisory Council members have referred to as the "blackletter" (as we do here to avoid confusion) is succinct and, starting with the third opinion, has become essentially a bulletpoint list of principles without citations or reasoning. ${ }^{121}$ The blackletter reads like a code provision or an official comment to a code provision, proclaiming for example that "punitive damages may not be awarded under Article 74 of the Convention" 122 or that "the Plain Meaning Rule does not apply under the CISG." 123 In some opinions, it sets out a principle of interpretation for the adjudicator to follow, such as "[i]n interpreting the words 'preponderant part' under Article 3(2) CISG, primarily an 'economic value' criterion should be used." 124 Jan Ramberg explained that the blackletter is the most important part of the entire document; while the Council takes responsibility for the entirety of the opinion, it "commits itself only to the blackletter text."125

While the blackletter is the most important section and is the most likely to be cited by a court or tribunal, the Advisory Council devotes the most space to the "comments" section of the opinion. The comments contain a comprehensive discussion of the CISG provision at issue and the Advisory Council's reasoning in the opinion. Unlike the blackletter, the comments section reads much like an academic journal article, filled with citations to case law, academic writings, and legislative history. In addition to providing critical analysis of select case law, Opinions Nos. 2 and 6 (which focus on areas of particularly divergent applications of the CISG) include, as annexes, lengthy, detailed tables

121. Mistelis interview, supra note 14; Ramberg interview, supra note 86.

122. See CISG Advisory Council Opinion 6, $\uparrow 9(\mathrm{~B})$, available at http://www.cisgac.com/ default.php?ipkCat $=128 \&$ ifkCat $=148 \&$ sid $=148 \#$ opinion.

123. See CISG Advisory Council Opinion 3, $\llbracket 2$, available at http://www.cisgac.com/ default.php?ipkCat $=128 \&$ ifkCat $=144 \&$ sid $=144$.

124. See CISG Advisory Council Opinion 4, 19 , available at http://www.cisgac.com/ default.php?ipkCat $=128 \&$ ifkCat $=146 \&$ sid $=146$.

125. Ramberg interview, supra note 86. 
describing decided cases from a variety of jurisdictions. ${ }^{126}$ A judge or arbitrator faced with a dispute over the timeliness of notice of non-conformity given under article 39 , for instance, could turn to Opinion No. 2 for a concise survey and analysis of existing case law and doctrine. This background might help a judge inexperienced with the CISG to understand better the Advisory Council's blackletter opinion. Splitting opinions into two sections undoubtedly gives the whole document a more official resonance. Had the Advisory Council chosen to render opinions without this structural and stylistic dichotomy, the opinions would have read more like any other academic commentary.

The opinions may be categorized as either "issue" or "article" opinions. "Issue opinions" discuss a broad issue which may encompass several CISG provisions. Opinion No. 1 discusses electronic communications under the CISG and touches upon several CISG provisions, while Opinion No. 3 addresses the applicability of the common law parol evidence and plain meaning rules in CISG disputes. On the other hand, "article opinions" seek to elucidate all of the major interpretive issues relating to a particular CISG provision or provisions. Opinion No. 2 discusses examination of the goods and notice of nonconformity under Articles 38 and 39, Opinion No. 4 discusses CISG Article 3 and mixed contracts, Opinion No. 5 discusses Article 49(1)(a) and the right to avoid a contract, and Opinion No. 7 discusses Article 79 and force majeure. These opinions read like excerpts from an official commentary to a convention. ${ }^{127}$

Most of the opinions address issues which have already led to divergent applications of the CISG. For example, Opinion No. 3 deals with "one of the most controversial matters in [the CISG's] implementation," namely the notice requirements under articles 38 and 39. ${ }^{128}$ The opinion fully exposes the various positions regarding the interpretation of articles 38 and 39. Similarly, Opinion No. 4 highlights disagreements over the meaning of the term "materials" in Article 3(1) CISG ${ }^{129}$ and whether "turnkey contracts" fall under the scope of Article 3(2)."130

While these opinions aim to correct past misunderstandings of the CISG, others seek to preempt possible future misinterpretations. Opinion No. 7 explains that relatively few cases have been litigated under Article 79 (excuses

126. See Opinion 6, supra note 122; CISG Advisory Council Opinion 2, available at http://www.cisgac.com/default.php?ipkCat=128\&ifkCat=144\&sid=144.

127. Many have called for the creation of an official commentary. See, e.g., James E. Bailey, Facing the Truth: Seeing the Convention on Contracts for the International Sale of Goods As an Obstacle to a Uniform Law of International Sales, 32 CORNELL INT'L L.J. 273, 290 (1999) (finding that "an official commentary to the CISG would be helpful"); See also Sim, supra note 74, at 21 . On the possible benefits and drawbacks of a comprehensive CISG official commentary, see infra, notes 199-202 and accompanying text.

128. See CISG Advisory Council Opinion 2, Comments, $\llbracket 1$, available at http://www.cisgac.com/default.php?ipkCat=128\&ifkCat $=144 \&$ sid $=144$.

129. See Opinion 4, supra note 124 , at Comments, $\$ 2.12$.

130. Id. ๆ 3.5 . 
for nonperformance such as force majeure); it therefore "focuses on a limited number of issues that are likely to provoke differences in interpretation in different jurisdictions." 131 It further emphasizes that the wording and legislative history of portions of Article 79 grant courts and arbitral tribunals "significant leeway." Thus, the opinion "focuses on those issues because they are the most likely to be treated in light of the arbitrator's or judge's national law; or at least the most susceptible to provoke divergent approaches."132

A judge or arbitrator looking for assistance in the interpretation of a CISG provision can easily access the Advisory Council opinions. The Advisory Council decided early on not to copyright its opinions or otherwise limit access to them. ${ }^{133}$ It has made the opinions available in all six of the official UN languages (Arabic, Chinese, English, French, Russian, and Spanish) as well as in German and Japanese. ${ }^{134}$ The opinions have been disseminated through a number of media, primarily by publication in academic journals, including the Pace International Law Review, the French-language Journal du Droit International, and the German-language Internationales Handelsrecht (which publishes the opinions in the original English and in translation). A number of online databases host Advisory Council opinions, including the Pace Law School database on International Commercial Law, ${ }^{135}$ a host of other websites forming part of the Autonomous Network of CISG Websites, ${ }^{136}$ and more recently through the Advisory Council's own site. ${ }^{137}$

At the time of writing, the Advisory Council is working on two new opinions which will be entitled "Claims for Damages Caused by Defective Goods or Services Under the CISG" and "Issues pertaining to Article 35 (conformity of goods)." Acting as rapporteurs are, respectively, Council member Hiroo Sono and former Secretary Loukas Mistelis.

131. See CISG Advisory Council Opinion 7, Comments, 94 , available at http://www.cisgac.com/default.php?ipkCat=128\&ifkCat=148\&sid=169.

132. Id. at Comments $\uparrow 5$ (calling the issue of turnkey contracts "highly controversial").

133. Mistelis interview, supra note 14.

134. See CISG Advisory Council, http://www.cisgac.com (last visited Mar. 9, 2009) [hereinafter "CISG Advisory Council"]. It should be noted that not all opinions are yet available in all of these languages. Translation of the opinions into German and Japanese has been courtesy of Professors Schwenzer and Sono, respectively.

135. See Loukas Mistelis, CISG-AC Publishes First Opinions, http://www.cisg.law.pace.edu/ cisg/CISG-AC.html. (last visited May 12, 2008).

136. The Autonomous Network of CISG Websites is a consortium of national and regional databases maintained by educational institutions and law firms. See Charter for the Autonomous Network of CISG Websites, available at http://cisgw3.law.pace.edw/cisg/charter.html. The Network "supports the efforts and work of the CISG Advisory Council that is aimed at promoting the uniform interpretation of the CISG." Id. at Section 3, Principle 6. Among the Network partners which cite to the Advisory Council Opinions are CISG Switzerland (http://www.cisgonline.ch/cisg/cisgac.html), CISG France (http://www.cisg-france.org/avis/avisCVIM.htm), CISG Denmark (http://www.cisg.dk/), and CISG Spain and Latin America (http://www.uc3m.es/cisg) websites.

137. See CISG Advisory Council, supra note 134. 


\section{B. The Legal Status of Advisory Council Opinions}

A variety of national and international bodies, official and unofficial, render advisory opinions. As a general rule, these opinions are authoritative but not binding. ${ }^{138}$ Often referred to as "soft law" because they are non-binding, advisory opinions nevertheless may encourage states or individuals to behave in a certain way. ${ }^{139}$

The CISG Advisory Council opinions are not binding on any nation or litigant, but the opinions do possess some measure of authority and, in this section, we consider the weight of the opinions. First however, the advisory opinions must be put in the context of the array of sources of legal authority on the CISG that affect how a court or arbitral tribunal will rule on a disputed issue.

When a court interprets a provision of the CISG and the plain language of the provision does not yield an obvious answer, it must turn to some other source of authority. The only authority that is truly binding on a court is the prior decision of a superior court in its jurisdiction on the same issue. However, except in a handful of countries (in particular Germany and China), few cases have considered the CISG, so there likely will not be any binding authority except on the most frequently litigated issues. ${ }^{140}$ For their part, there is no binding precedent among arbitral tribunals. We can therefore expect adjudicators to turn to non-binding (persuasive) authority in a majority of disputes arising under the CISG.

A variety of persuasive authorities on the CISG exist and are available to courts and arbitral tribunals. ${ }^{141}$ These sources of authority include the CISG's travaux préparatoires, foreign court and arbitral decisions, the Secretariat Commentary, and scholarly writings, which continue to proliferate. ${ }^{142}$ Even common law judges, who traditionally discount references to academic writings, appear to be more likely to refer to them when called upon to interpret the CISG. ${ }^{143}$

138. See Schmid, supra note 92 , at 415 .

139. Id.

140. The only issue of CISG interpretation on which there is significant precedent within the U.S. is the interpretation of contracts governed by the CISG, in particular the applicability of the parol evidence and plain meaning rules. See, e.g., MCC-Marble Ceramic Ctr., Inc. v. Ceramica Nuova d'Agostino, S.p.A., 144 F.3d 1384 (11th Cir. 1998); Shuttle Packaging Sys. v. Jacob Tsonakis, INA, S.A., No. 1:01-CV-691, 2001 U.S. Dist. LEXIS 21630 (W.D. Mich. Dec. 17, 2001).

141. On the proper interpretive methodology for the CISG, see supra, part II.B.

142. Spaic, supra note 67, at 253-54. See also HONNOLD, UNIFORM LAW, supra note 52, at 183 ("This massive outpouring of writing about the Convention [is a] testimonial to the world-wide interest in international legal unification.").

143. Many, if not most, of the American decisions interpreting the CISG have relied on publications by CISG scholars. See, e.g., Zapata Hermanos Sucesores, S.A. v. Hearthside Baking Co., No. 99 C 4040, 2001 WL 1000927, *4 (N.D. Ill., Aug. 29, 2001) (citing Peter Schlechtriem and John Gotanda); MCC-Marble 144 F.3d 1384, at 1389 (citing Allen Farnsworth); TeeVee Toons, 2006 WL 2463537, at *3 (citing Allen Farnsworth); Usinor Industeel v. Leeco Steel Products, Inc., $209 \mathrm{~F}$. Supp. 2d 880, 885 (N.D.Ill., 2002) (citing John Honnold); Miami Valley Paper, LLC v. Lebbing 
When faced with a dispute arising under the CISG, a court or arbitral tribunal may look to all of these persuasive sources of authority, as well as to any relevant Advisory Council opinions. Four core observations regarding the legal status of the Advisory Council opinions may be made.

First, whatever authority the Advisory Council may have is due to "the stature of its members." 144 Because the Advisory Council is composed of scholars well-known in the CISG academic community, its opinions carry significant weight, and certainly more weight than if the council were composed of less-known and less-experienced scholars. Even those critical of the Advisory Council tend to acknowledge the prominence of its members. ${ }^{145}$ Second, the opinion of a body of scholars speaking with one voice should carry more weight than that of one scholar speaking alone. Third, the Advisory Council is constituted and acts as if it were an official body. Although it is careful always to disclaim any official status, its official-seeming title and procedures and the code-like concision of the blackletter part of its opinions give it an air of authority, which may be especially effective in convincing a judge or arbitrator unfamiliar with CISG jurisprudence and doctrine. ${ }^{146}$ Fourth, and on the other hand, the opinions would undoubtedly carry more weight if they were the product of an official UNCITRAL body. Many references in the academic literature to Advisory Council opinions contain caveats to this effect. For example, Sim notes that, "[s]ince the CISG Advisory Council is a private initiative, its opinions would not carry the imprimatur of UNCITRAL."147

The best way to test these propositions about the authority of the CISG Advisory Council is to imagine situations in which its opinions conflict with

Engineering \& Consulting GmbH, No. 1:05-CV-00702, 2006 WL 2924779, 3 (S.D. Ohio, Oct. 10, 2006) (citing Joseph Lookofsky); Valero Marketing \& Supply Company v. Greeni Oy, No. Civ. 015254(DRD), 2006 WL 891196,8 n.3 (D.N.J. Apr. 10, 2006) (citing Bruno Zeller).

On this issue, see Ferrari, supra note 3, at 209 Footnote 141 (citing Honnold, supra note 10, at 208, for the proposition that " $[t]$ raditional barriers to the use of scholarly writing in legal development broke down a long time ago in this country and is breaking down in citadels of literalism in other parts of the common law world, especially in the handling of international legal materials."). On the use of academic writings to interpret uniform laws, see generally Edgar Bodenheimer, Doctrine as a Source of the International Unification of Law, 34 AM. J. CoMP. L. (Supplement) 67, 71 (1986) (asking "whether doctrinal writings may be considered primary authorities of law on a par with legislation and (in some legal systems) court decisions, or whether they must be relegated to the status of secondary sources").

144. Sim, supra note 74 , at 21 .

145. See Joseph Lookofsky \& Harry Flechtner, Zapata Retold: Attorneys' Fees are (Still) Not Governed by the CISG, 26 J.L. \& COM. 1, 7 (2006-2007) (conceding that the Advisory Council "is certainly a distinguished group of scholars" despite a critical analysis of its role and authority).

146. This is not coincidental; indeed, it was "a matter of conscious decision to opt for a certain authoritative style." Mistelis interview, supra note 14.

147. Sim, supra note 74 , at 21 . See also Lookofsky \& Flechtner, supra note 145, at 7 (stating that the fact that the Advisory Council is a "(private) body gives [its] opinions no more inherent authority concerning the meaning of the CISG than the opinions of other scholars"); Sheaffer, supra note 96 , at 483 (arguing that "it would be necessary to expand the current council and establish a 'Permanent Editorial Board"'). 
other sources of persuasive authority. For the reasons described, if an Advisory Council opinion conflicts with a scholarly writing on the CISG, a judge or arbitrator is more likely to follow the Advisory Council opinion, because it is more likely to represent a scholarly consensus and seems to have an official imprimatur. Slightly more uncertain would be a conflict between an Advisory Council opinion and the decision of a foreign or non-superior domestic court. The result will depend on the practice of the jurisdiction in which the court sits and the circumstances surrounding the prior decision of the foreign or nonsuperior court-for instance, whether it is an isolated decision, from a foreign or domestic court, and from an appellate or lower court.

In the end, such determinations will necessarily be made on a case-by-case basis. This underlines the essential truth about the Advisory Council's authority and the status of its opinions: they depend on their reception. As Oliver Wendell Holmes famously put it, the law is what judges do, ${ }^{148}$ so the authority of the Advisory Council exists only to the extent that courts and tribunals rule according to its interpretations of the CISG. This may occur directly, in the form of citations to Advisory Council opinions in judgments or arbitral awards, or indirectly, where the Advisory Council shapes the academic debate, helping to form an academic consensus that presumably will, in turn, shape the decisions of adjudicators. In the two sections that follow, we explore the impact that the Advisory Council has had by tracing the response of adjudicators and scholars to its opinions.

\section{Citation of CISG-AC Opinions by Courts and Arbitral Tribunals.}

The primary means by which the CISG-AC may promote interpretive uniformity is direct influence on adjudicators-courts and arbitral tribunals. To the authors' knowledge, only courts in Germany and, in single instances, in the United States and Poland, ${ }^{149}$ have cited Advisory Council opinions. The TeeVee Toons decision ${ }^{150}$ remains the only published instance to date of an English language judicial or arbitral citation of a CISG-AC opinion. In TeeVee Toons, the plaintiffs were owners of a patented design for the "Biobox," a secure, environmentally-friendly way to package audio and video cassettes. After protracted negotiations, they contracted with defendant Gerhard Schubert GmbH in February 1995 to develop a manufacturing system to mass produce the Biobox. The contract expressly named the CISG as its governing law. ${ }^{151}$

Almost immediately, problems arose; first, production delays set the project back two years and then, when the production system was finally

148. Oliver Wendell Holmes, Jr., The Path of the Law, 10 HARV. L. Rev. 457 (1897).

149. Spoldzielnia Pracy "A" v. M.W.D. GmbH \& Co. KG, 11 May 2007 [V CSK 456/06] (decision of the Supreme Court of Poland, stating that it was "important to note" the content of CISG-AC Opinion No. 5).

150. TeeVee Toons v. Gerhard Schubert GmbH, 2006 WL 2463537 (S.D.N.Y. 2006).

151. Id. at $* 1$. 
completed and delivered, it malfunctioned frequently and severely. The plaintiffs commenced the action in July 2000, asserting both contractual and tort claims.

A central issue in the dispute was whether provisions in the "Terms and Conditions" attached to the contract effectively disclaimed any applicable warranties; the plaintiffs claimed that the parties had reached an "express oral understanding" that the boilerplate disclaimers in the Terms and Conditions would not apply. ${ }^{152}$ Under American contract law, such an oral agreement would be inadmissible parol evidence. ${ }^{153}$ However, the court found that the CISG requires the admission of such evidence. ${ }^{154}$

The defendants in TeeVee Toons also argued that a merger clause in the final contract precluded the introduction of evidence of oral representations made by them during the parties' negotiations. The court discussed some of the few American precedents decided under the CISG. ${ }^{155}$ However, the court distinguished these cases on the facts, then stated-without hesitation or ceremony - that " $[t]$ he Court thus turns to the text of the CISG, as interpreted by the CISG Advisory Council." 156

The court wrote that the CISG-AC "has noted that "extrinsic evidence [such as the oral dealings between Schubert and TVT representatives] should not be excluded, unless the parties actually intend the Merger Clause to have this effect' and that 'Article 8 requires an examination of all relevant facts and circumstances when deciding whether the Merger Clause represents the parties' intent." 157 The Court then held that the merger clause at issue in TeeVee Toons would have been binding only if the parties so intended, noting in a footnote that this interpretation was in accord with the CISG-AC's observation that "Articles 8 and 11 express the general principle that writings are not to be presumed to be 'integrations."'158 Perhaps even more remarkably, the court went on in the same footnote to quote with approval (although with a caveat that it is not per se applicable) a provision of the Principles of European Contract Law to which the CISG-AC referred in its opinion. It also cited Article 7(1) CISG, which, in the court's words, requires that "the notion of 'good faith in international trade'

152. Id. at *6.

153. E. ALLEN FARNSWORTH, CONTRACTS $\$ 7.3$ (3d ed. 1999).

154. The court's actual statement, while correct, misses the point: "Unlike American contract law, the CISG contains no statute of frauds." Id. at *7 (citing Atla-Medine v. Crompton Corp., No. 00 Civ. 5901 (GB), 2001 WL 1382592, at $* 5$ n. 6 (S.D.N.Y. Nov. 7, 2001)). For the more general proposition that the CISG does not require a writing to create an enforceable contract, the court also cited a scholarly article, Larry DiMatteo et al., The Interpretive Turn in International Sales Law: An Analysis of 15 Years of CISG Jurisprudence, 34 NW. J. INT'L L. \& BUS. 229, 437 n. 872 (2004).

155. Usinor Industeel, 209 F. Supp. 2d 880, at 884; MCC-Marble, 144 F.3d 1384, at 1391.

156. TeeVee Toons, 2006 WL 2463537 at $* 8$.

157. Id. (quoting CISG-AC Opinion no. 3, supra note 123, \ 4.5).

158. Id. n. 2 . 
must underlie any CISG interpretation."159

The TeeVee Toons court justified its reliance on the CISG-AC as a source of authority with a single quotation from the Delchi Carrier case: "[b]ecause there is virtually no case law under the Convention, we look to its language and to 'the general principles' upon which it is based."160 Moreover, the court's reliance on Delchi Carrier is both puzzling and unsatisfactory. First, the quotation is somewhat beside the point: it refers to the CISG's general principles but does not state what sources a court should look to in order to determine the content of those principles. Delchi Carrier says nothing about the propriety or force of citing the opinion of a group of academics calling itself the CISG Advisory Council.

Second, the quotation is outdated. Delchi Carrier was decided in 1996, a time when there was, in fact, not a great deal of U.S. case law interpreting the CISG. However, by the time the decision in TeeVee Toons was written, ten years had passed, during which time several cases had been decided under the CISG in U.S. courts. ${ }^{161}$ In addition, over the course of those ten years, U.S. courts had become more comfortable with citing foreign judgments for their interpretations of CISG provisions. ${ }^{162}$

Third, and perhaps most importantly, the quotation enshrines an error of law, as the Delchi Carrier court misconstrued Article 7(2) CISG. Reliance on "general principles" in interpreting the CISG is not a fallback position to be resorted to when case law within the court's jurisdiction is inadequate. Rather, case law on the CISG is a potential source of authority as to the content and effects of those general principles. ${ }^{163}$

The reader is left with the impression that no underlying interpretive program led the TeeVee Toons court to cite a CISG-AC opinion. However, even though the TeeVee Toons court's citation to the CISG-AC opinion is seriously flawed, the Advisory Council and its supporters should still take heart in the decision. While a ringing endorsement of international and scholarly sources of interpretive authority on the CISG might have been more satisfying, implicit acceptance of the CISG-AC's authority is a stronger foundation for long-term legitimacy.As mentioned above, no other court in America has cited a CISG-AC opinion. Moreover, of the small number of cases that cite TeeVee Toons, none cites it for the proposition for which it relied on the Advisory Council opinion; all references to TeeVee Toons in subsequent case law pertain to unrelated issues. Similarly, no subsequent court decision, to our knowledge has cited the Polish Supreme Court's decision in Spoldzielnia Pracy. Despite this, however,

159. Id.

160. Id. at *8 (quoting Delchi Carrier S.p.A. v. Rotorex Corp., 71 F. 3d 1024, 1027-28 (2d Cir. 1995) (quoting CISG art. 7(2))).

161. Spaic, supra note 67, at 245 (describing increase in CISG decisions in American courts).

162. See supra notes 113-119 and accompanying text.

163. See supra notes $54-55$ and accompanying text. 
the CISG-AC has now indisputably made the leap from mere academic commentary to a direct influence on judges and, therefore, an indirect influence on the evolving law of the CISG.

\section{Receipt of CISG-AC Opinions by the Academic Community}

In addition to direct influence on adjudicators, the CISG-AC can also contribute to uniform interpretation by helping shape academic opinion. As discussed above, CISG interpretive methodology encourages citation of scholarly commentary, so academics may have a greater-than-usual influence on CISG jurisprudence (at least, greater than is usual in common law courts). Of course, any persuasive argument in an academic publication has the power to influence others; CISG-AC opinions, as the collective wisdom of a diverse group of prominent CISG scholars, could carry more weight within the academic community than the writings of an individual, but this is not a certainty. If other academics object to the concept of a private initiative like the CISG-AC, reject the reasoning of a given CISG-AC opinion, or simply ignore the products of CISG-AC deliberations, then its opinions will have little or no influence.

The academic community has in fact taken greater notice of the CISG-AC than have the courts. This may be unsurprising, given that the CISG-AC members are themselves prominent in the CISG scholarly community. However, academic reaction to the CISG-AC has been, for the most part, neither explicitly positive nor explicitly negative. No article that we know of has been published in English specifically about the CISG-AC. (One article has been published in German, but in 2003, just after the first CISG-AC opinion was promulgated, and it is very brief.) ${ }^{164}$ Only four articles published in English include any actual discussion or analysis of a CISG-AC opinion. ${ }^{165}$ However, at least ten articles and one book chapter mention the CISG-AC, largely without further comment (although several of these are published presentations from a single symposium). ${ }^{166}$ More significantly, at least sixteen articles in academic

164. Rolf Herber, Eine neue Institution: Der CISG Advisory Council, 3 INTERNATIONALES HANDELSRECHT 201 (September/October 2003).

165. Juana Coetzee, Securing the Future of Electronic Sales in the Context of International Sales, 11 VINDOBonA J. INT'L COM. L. \& ARB. 11 (2007); Alberto Luis Zuppi, The Parol Evidence Rule: A Comparative Study of the Common Law, the Civil Law Tradition, and Lex Mercatoria, 35 GA. J. INT'L \& COMP. L. 233 (2007); Lookofsky \& Flechtner, supra note 145; Wolfgang Hahnkamper, Acceptance of an Offer in Light of Electronic Communications, 25 J.L. \& COM. 147 (2005).

166. John Felemegas, Introduction, in AN INTERNATIONAL APPROACH TO THE INTERPRETATION OF THE UNITED NATIONS CONVENTION ON CONTRACTS FOR THE INTERNATIONAL SALE OF GOODS (1980) AS UNIFORM SALES LAW, at $8 \mathrm{n}$. 25 (John Felemegas ed., 2007) (describing the CISG-AC and characterizing its establishment as a "significant development"); Sheaffer, supra note 96 , at 482 (arguing for establishment of a robust "official" council on the CISG and noting that "a limited council for international sales law is already in existence and has been issuing advisory opinions for a number of years under the guidance of UNCITRAL"); Adam M. Giuliano, 
journals cite a CISG-AC opinion for a point of law, ${ }^{167}$ as do the best-known

Nonconformity in the Sale of Goods Between the United States and China: the New Chinese Contract Law, the Uniform Commercial Code, and the Convention on Contracts for the International Sale of Goods, 18 FLA. J. INT'L L. 331, 332 n. 3 (2006) (describing CISG-AC Opinion No. 2 as a source of authority on CISG articles 38 and 39); Marek Dubovec, CISG and the Unification of International Trade Law, 2008 INT. T.L.R. 14(2), 45 (reviewing BRUNO ZELLER, CISG AND THE UNIFICATION OF INTERNATIONAL TRADE LAW (2006)) (observing that a weakness of Zeller's book is that it does not "refer[] to the Opinions of the International Sales Advisory Council (CISG-AC) that provide useful interpretation of various provisions of the CISG, contributing to the uniformity of interpretation and application of the Convention."); Schlechtriem, supra note 5 (noting the discussion in CISG-AC Opinion No. 4 of the "preponderant part" standard in CISG article 3); Nicholas Whittington, Comment on Professor Schwenzer's Paper, 36 VICT. U. WELLINGTON L. REV. 809 n. 9 (2006) (citing CISG-AC Opinion No. 2 for its observation that many courts interpreting CISG articles 38 and 39 have analogized from provisions of domestic law); Luke Nottage, Who's Afraid of the Vienna Sales Convention (CISG)? A New Zealander's View from Australia and Japan, 36 VICT. U. WELLINGTON L. REV. 815, 839 (2006) (simply noting the establishment of the CISG-AC); Andersen, supra note 10, at $162 \mathrm{n} .12$ (referring reader to the discussion of reasonable time for giving notice in CISG-AC Opinion No. 2); Filip De Ly, Sources of International Sales Law: An Eclectic Model, 25 J.L. \& COM. 1, 7 n. 12 (2005) (noting the discussion in CISG-AC Opinion No. 4 of difficulties in interpretation relating to the delivery of goods for construction or infrastructure projects); Clayton P. Gillette \& Robert E. Scott, The Political Economy of International Sales Law, 25 INT'L REV. L. \& ECON. 446, 460 n. 40 (2005) (noting the discussion in CISG-AC Opinion No. 2 of the debate at the Vienna Diplomatic Conference between representatives of countries with strict notice requirements and those from countries that had no notice requirements); Lookofsky, supra note 57, at $194 \mathrm{n} .99$ (describing the CISG and noting that, as a private initiative and unlike the UNCITRAL case Digesters, the CISG-AC "is afforded the luxury of being critical").

167. Stephan W. Schill, Enabling Private Ordering: Function, Scope, and Effect of Umbrella Clauses in International Investment Treaties, 18 MINN. J. INT'L L. 1 (2009) (citing CISG-AC Opinion No. 7 as authority on whether the CISG permits a party to withdraw its obligations when faced by non-performance by the other party); Alicia Jurney Whitlock and Boris S. Abbey, Who's Afraid of the CISG? -Why North Carolina Practitioners Could Learn a Thing or Two About the 1980 United Nations Convention on Contracts for the International Sale of Goods, 30 CAMPBELL L. REV. 275 (2008) (stating that the Advisory Council "expressly rejected the parol evidence rule"); Lachmi Singh and Benjamin Leisinger, $A$ Law for International Sale of Goods: A Reply to Michael Bridge, 20 PACE INT'L L. REV. 161 (2008) (citing various portions of CISG-AC Opinion No. 5); Trevor Perea, Treibacher Industrie A.G. v. Allegheny Technologies, Inc.: A Perspective on the Lackluster Implementation of the CISG by American Courts, 20 PACE INT'L L. REV. 191 (2008) (citing CISG-AC Opinion No. 3 to the effect that the CISG does not include the parole evidence rule); Charles H. Martin, The Electronic Contracts Convention, the CISG, and New Sources of ECommerce Law, 17 TUL. J. INT'L \& COMP. L. 467, 471, 475 (2008) (describing the conclusions of CISG-AC Opinion No. 1 and stating that it will survey "the current sources of international electronic contract rules, including the rules of the CISG as interpreted by its Advisory Council"); Peter Schlechtriem, Non-Material Damages - Recovery Under the CISG?, 19 PACE INT'L L. REV. 89, 90 (2007) (citing CISG-AC Opinion No. 6 to the effect that the Advisory Council "has confirmed" the "prevailing view [that] non-pecuniary damages cannot be compensated under the damages provision of the CISG); Ingeborg Schwenzer, National Preconceptions that Endanger Uniformity, 19 PACE INT'L L. REV. 103, 120-123 (2007) (describing CISG-AC Opinion No. 2 in detail but avoiding any characterizations as to the opinion's legal status); Francesco G. Mazzotta, Notes on the United Nations Convention on the Use of Electronic Communications in International Contracts and its Effects on the United Nations Convention on Contracts for the International Sale of Goods, 33 RUTGERS COMPUTER \& TECH. L.J. 251, 271 n. 99 (2007) (citing CISG-AC Opinion No. 1 for the proposition that contracts under the CISG may be negotiated and concluded entirely by electronic means); Karen Halverson Cross, Parol Evidence under the CISG, the "Homeward Trend" 
treatise on the CISG, ${ }^{168}$ a textbook aimed at students of international sales law, ${ }^{169}$ a multi-volume looseleaf manual aimed at practitioners, ${ }^{170}$ three practitioner guidebooks written by academics and published by West, ${ }^{171}$ and a 2007 American Bar Association-sponsored Continuing Legal Education lecture, also published by West. ${ }^{172}$ Taken together, these references indicate that academics who write on the CISG are not only aware of the CISG-AC and its opinions, but consider these to be reliable sources of authority on controversial matters of interpretation.

Reconsidered, 68 OHIO ST. L.J. 133, 137 n. 19, 148 n. 68 (2007) (citing CISG-AC Opinion No. 3 for its characterization of the MCC-Marble case as a "leading" American decision under the CISG and its assertion that the CISG drafters rejected any application of the parol evidence rule); Matthew Scherer \& Michael E. Schneider, International Construction Contracts under Swiss Law, ConST. L.J. 2007, 23(8), 559, 560 (noting that CISG Advisory Opinion No. 4 contradicts some recent case law in Switzerland); Sarah Green \& Djakhongir Saidov, Software as Goods, J.B.L. 2007, MAR, at 172 (citing CISG-AC Opinion No. 4 for its interpretation of the "preponderant part" requirement in article 3 CISG for the applicability of the CISG); Felix Lautenschlager, Current Problems Regarding the Interpretation of Statements and Party Contracts under the CISG - the Reasonable Third Person, Language Problems and Standard Terms and Conditions, 11 V. J. INT'L COM. L. \& ARB. 259, 261 n. 13. (2007) (citing CISG-AC Opinion No. 3 as the "dominant opinion" on the nonapplicability of the parol evidence rule under the CISG); Peter Huber, CISG-The Structure of Remedies, 71 RABELS ZEITSCHRIST FÜR AUSLÄNDISCHES UND INTERNATIONALES PRIVATRECHT 13, $31 \mathrm{n}$. 70 (January 2007) (citing CISG-AC Opinion No. 5 for its statement that fundamental breach doctrine under the CISG adequately covers situations where the commercial background of the transaction requires clear criteria for the decision on whether to terminate the contract), available at http://www.cisg.law.pace.edu/cisg/CISG-AC-op5.html\#1; Peter Schlechtriem, Subsequent Performance and Delivery Deadlines-Avoidance of CISG Sales Contracts Due to Non-Conformity of the Goods, 18 PACE INT'L L. REV. 83, 83 n. 3 (2006) (Todd Fox, tr.) (citing CISG-AC Opinion No. 5, inter alia, for its explanation of why the standard for avoidance of the contract under the CISG is stricter than under German domestic law); Anselmo Martinez Cañellas, The Scope of Article 44 CISG, 25 J.L. \& COM. 261, 264 (2005) (quoting CISG-AC Opinion No. 2 to the effect that CISG article 44 is not necessary, as articles 38 and 39 "contain language that can fairly be interpreted to reach any result that article $\mathbf{4 4}$ was intended to reach").

168. COMMENTARY ON THE UN CONVENTION ON THE INTERNATIONAL SALE OF GOODS (CISG) (Peter Schlechtriem \& Ingeborg Schwenzer, eds.) (2d English ed. 2005). This work, the only major, comprehensive CISG treatise to have published a new edition since the Advisory Council was established, contains multiple citations to CISG-AC Opinions on points of interpretation. This is, however, unsurprising to the extent that it was edited by two members of the Advisory Council and that several relevant sections of the treatise were written by Professors Schlechtriem and Schwenzer.

169. Peter Huber \& Alastair MUllis, THE CISG-A NeW TEXTBOOK FOR STUdENTS AND PrACTITIONERS 235 n. 68 (2007) (citing CISG-AC Opinion No. 3 to the effect that the common law parol evidence and plain meaning rules have no place in the CISG ).

170. Albert H. Kritzer, Sieg Eiselen, Jessica Vanto, Jarno J Vanto, International CONTRACT MANUAL (last updated May 13, 2009). This frequently-updated manual is produced primarily under the direction of two Advisory Council members and under the auspices of the Professor Kritzer's Pace Institute of International Commercial Law.

171. The West Guide to the INTERnational. Sale of GoOdS CONVENTION, § 1:32 (2008); LAWS OF INTERNATIONAL TRADE, vol. $2, \S 66: 32$ (2008); MODERN LAW OF CONTRACTS $§ 23: 22$ (2008).

172. Amelia H. Boss, American Law Institute - American Bar Association Continuing Legal Education, ALI-ABA Course of Study: Current Developments in Sales of Goods Under Article 2 and in International Sales of Goods Under CISG (June 7-8, 2007). 
Perhaps most striking is a short article by Wolfgang Hahnkamper, adapted from a presentation he made at the CISG $25^{\text {th }}$ anniversary conference organized by UNCITRAL. This article discusses the CISG's rules on acceptance of offers as they relate to electronic communications. ${ }^{173}$ Hahnkamper notes that a new UN treaty, not yet approved by the General Assembly, could be expected to resolve ambiguities relating to the CISG's treatment of electronic communications. ${ }^{174}$ However, until such treaty comes into force, the CISGAC's Opinion No. 1 "is the applicable interpretation of the CISG with regard to electronic communications." "175 This uncritical assertion-that the CISG-AC's opinion is not just persuasive, not merely correct or trustworthy, but "applicable"-is echoed throughout the article.

An article by Juana Coetzee takes a more detailed look at Opinion No. 1. ${ }^{176}$ There has been some dispute as to whether the CISG governs electronic communications, and Coetzee generally agrees with the CISG-AC's analysis. She recognizes the CISG-AC's product to be mere "scholarly interpretative commentary," 177 but-without supporting citations-asserts that Opinion No. 1 "reflects modern scholarly opinion on this matter."178 In the end, she praises Opinion No. 1 for "confirming the validity of electronic contracts and notices" but remarks that, since "this opinion has no official status . . . in the absence of party agreement on electronic communications ... uncertainty remains."179 Thus, Coetzee appears to treat the CISG-AC opinions as she would other academic writings, but accords them particular persuasive authority to the extent that they express the scholarly consensus.

In a 2007 comparative study of the parol evidence rule, Alberto Zuppi dedicates considerable attention to CISG-AC Opinion No. 3.180 Zuppi focuses on the discussion of "merger" (or "entire agreement") clauses, by which parties may agree to exclude parol evidence, even if the governing substantive law would permit the judge to consider it. In particular, Zuppi takes issue with the CISG-AC's conclusion that agreed-upon merger clauses may validly derogate from the interpretive rules in the CISG, which would otherwise permit

173. Hahnkamper, supra note 165.

174. The United Nations Convention on the Use of Electronic Communications in International Contracts, G.A. Res. 60/21, U.N. Doc. A/RES/60/21 (Dec. 9, 2005). As of June 2008, eighteen countries have signed the Convention. However, the three ratifications necessary for the Convention's entry into force have not yet occurred. For current status of the Convention, see http://www.uncitral.org/uncitral/en/uncitral_texts/electronic_commerce/2005Convention_status.htm $l$.

175. Hahnkamper, supra note 165 , at 148.

176. Coetzee, supra note 165 .

177. Id. at 16.

178. Id. at 12.

179. Id. at 24 .

180. Zuppi, supra note 165 , at 268-71. 
consideration of parol evidence. ${ }^{181}$ In doing so, he treats the CISG-AC opinion as a writer might any other academic argument; there is no discussion in Zuppi's article of the CISG-AC's role except for an aside that "this initiative . . . has been praised." 182

Lookofsky and Flechtner, two scholars widely published on the CISG, have taken a decidedly negative view of the CISG-AC. In an article discussing developments relating to the recoverability of attorneys' fees under the CISG, they take issue not only with the CISG-AC's opinion, but also apparently with the Advisory Council itself. ${ }^{183}$ The CISG-AC opinion at issue refers to a U.S. Federal Court decision awarding attorneys' fees in a case governed by the CISG. ${ }^{184}$ Although Lookofsky and Flechtner agree with the CISG-AC's "clear and unequivocal" opinion that attorneys' fees cannot be recovered under the CISG, they criticize the CISG-AC for its characterization of the substanceprocedure distinction as "outdated and unproductive." 185

As Lookofsky and Flechtner point out, the CISG drafters themselves referred to the substance-procedure distinction in their deliberations on the proper scope of the CISG. ${ }^{186}$ They therefore probably have the better argument that this distinction has a role in interpreting the CISG. However, they go beyond criticizing the CISG-AC's approach and assert that it "appears to be based on a misunderstanding of the role and authority of the Advisory Council itself." 187 In essence, their argument is that since the CISG drafters employed the substance-procedure distinction, the CISG-AC has no authority to declare it "outdated and unproductive." Lookofsky and Flechtner point out that the CISG$\mathrm{AC}$ is not an "international legislature" and that "organizing themselves into a (private) body gives their opinions no more inherent authority . . . than the opinions of other scholars." 188 Moreover, where "their opinions depart from the intention of those who have actual law-making authority . . . the Council's opinions have no authority whatsoever." 189 They conclude that it is "absurd to think that an Advisory Council Opinion can render the substance-procedure distinction irrelevant." 190

181. Id. at $270-271$.

182. Id. at 269 (citing Herber, supra note 164 , at 201-02).

183. Lookofsky \& Flechtner, supra note 145 , at 7.

184. Zapata Hermanos Sucesores, S.A. v. Hearthside Baking Co., No. 99-C4040, 2002 WL 398521 (N.D. Ill. Aug. 28, 2001), rev'd, 313 F.3d 385 (7th Cir. 2002), cert. denied, 540 U.S. 1068 (2003).

185. Lookofsky \& Flechtner, supra note 145 , at 5.

186. Id. at 6-7 (quoting UNCITRAL, Report of the Committee of the Whole Relating to the Draft Convention on the International Sales of Goods 97 177-78 (1977), reprinted in HONNOLD, DOCUMENTARY HISTORY, supra note 3, at 330).

187. Id. at 5 .

188. Id. at 7 .

189. Id.

190. Id. 
Lookofsky and Flechtner protest too much. What they say about the CISG$\mathrm{AC}$ is correct; however, caveats about its official-seeming trappings aside, the CISG-AC has never arrogated to itself any greater authority than that of the collective opinion of a diverse group of prominent academics. It is therefore something of a straw man argument to assert so vociferously that the CISG-AC does not have authority it has never claimed to possess. In addition, the debate over the propriety of the substance-procedure distinction (in the interpretation of the CISG or generally) is exactly the sort of debate in which academics love to engage and for which scholarly publications are well suited.

Taken together, this record of commentary indicates that the CISG academic community has taken notice of the CISG-AC and is willing to treat it as a source of authority, in many cases beyond the authority of a single scholar writing alone. Even in the article most critical of the CISG-AC, Lookofsky and Flechtner's broadside indicates that, if they are not prepared to relinquish any "power" to the CISG-AC, they are willing to grapple with its opinions as they would the theories of a leading academic. On the other hand, some commentators already consider CISG-AC opinions to be "the applicable" interpretations in the areas which they discuss. On the whole, CISG-AC opinions carry considerable weight in the academic community and therefore serve to shape the discussion of controversial CISG provisions and promote uniformity of academic opinion.

IV.

\section{THE CISG AdVISORY COUNCIL IN THE GLOBAL JURISCONSULTORIUM}

The CISG-AC cannot be assessed in isolation. Its contributions to a more uniform interpretation of the CISG are made as part of the global CISG jurisconsultorium. As Andersen notes, the CISG has been "taken from the hands of the scholars who drafted it and been placed firmly in the hands of the practitioners." 191 However, despite this symbolic handover of the CISG from academics to practitioners, interpretive efforts "never abated on the scholarly side. One testament to this is the existence of the CISG Advisory Council." 192 Moreover, UNCITRAL continues to have a role in promoting uniform interpretation of its creation.

Thus, before considering the proper role of the CISG-AC, this section will discuss the strengths and weaknesses of interpretations by other participants in the CISG jurisconsultorium: UNCITRAL, courts and tribunals, and commentators. Each of these actors contributes to the development of CISG doctrine in different ways and with different benefits and drawbacks. We conclude that the CISG-AC, both despite and because of its unofficial status, occupies a singular and important position in the jurisconsultorium.

191. Andersen, supra note 10 , at 162-63.

192. Id. at 178. 


\section{A. Centralized and Decentralized Interpretation of the CISG}

Interpretation of the CISG can proceed in a centralized or decentralized manner: either an official body will be vested with the power to determine the meaning of CISG provisions or a large number of individuals and institutions will weigh in, with none of them having the power to bind the others. The only institution which could issue official interpretations of the CISG (or empower another body to do so) is UNCITRAL. Moreover, as Bonell has argued, since the CISG "was elaborated within UNCITRAL, the Commission itself should ultimately be responsible for promoting ... uniform interpretation and application." 193

There is currently no "consistent, official, systematic commentary within the field of international sales law."194 Perhaps the most direct path to uniformity would be to provide just such an official, systematic commentary. However, the only interpretive initiative to which UNCITRAL has given its imprimatur is a digest that collects and disseminates case law on the CISG-a decentralized source of authority that will be discussed below. Centralized interpretations promulgated under the auspices of UNCITRAL could come in two forms: a comprehensive set of official comments to the CISG or an advisory body that would render interpretations on particular CISG issues - essentially, an official version of the CISG-AC. These will be discussed in turn.

As noted above, courts and tribunals have referred to the Secretariat Commentary to the 1978 Draft of the CISG as if it were a set of official comments. ${ }^{195}$ This tendency indicates that courts are eager to grasp clearly worded, comprehensive commentaries, if available. With respect to other uniform laws, "[E]xperience has shown that courts defer . . . to the guidance [official] Comments offer as to the proper application of Code provisions."196 This deference can be leveraged to aid in uniform interpretation of the CISG.

Here again, the American experience with the UCC can be instructive. Although the official comments to the UCC have been criticized in various respects, they undoubtedly "provide a relatively cohesive and uniform elaboration of purposes, policies and applications of the UCC." 197 Perhaps more importantly, because the UCC official comments accompany the official legislative product and are widely promulgated among all members of the bench and bar, "they enjoy a perceived stature beyond their actual importance, which aids uniformity." 198 Their comprehensiveness and status have made the UCC

193. Bonell, supra note 24, at 242.

194. Sheaffer, supra note 96 , at 492 .

195. See supra notes 75 and 76 and accompanying text.

196. Sean Michael Hannaway, The Jurisprudence and Judicial Treatment of the Comments to the Uniform Commercial Code, 75 CORNELL L. REV. 962 (1990) (discussing the use of the UCC Comments by courts interpreting the UCC).

197. Murray, supra note 23, at 378.

198. Id. 
official comments "by far the most useful aids to interpretation and construction," which American courts have taken to "like a duck to water." 199

For these reasons, Murray argues that the promulgation of a set of official comments is the most promising "workable solution" to the problem of nonuniform interpretation:

[Compiled comments] could eliminate manufactured difficulties and become a major force in promoting familiarity and use of the Convention through a reasoned analysis of the purpose of each Article, in pursuit of the general purposes and policies of the entire Convention. They can unfold a consistent analysis that promotes the general principles of CISG. ${ }^{200}$

The promulgation of an official commentary by UNCITRAL could be a boon to uniform interpretation. It would also provide an opportunity to revisit issues that have been affected by the advance of technology (such as the matters relating to electronic communications that are considered in CISG-AC Opinion No. 1) and draw on twenty years of experience with the CISG. Disputes over interpretation could be dealt with comprehensively and systematically.

However, even without amendments to the text of the CISG, the UNCITRAL member states will still have to approve any set of official comments. This process will likely require a great deal of negotiation-a lengthy and expensive proposition. ${ }^{201}$ Moreover, the compromise and horsetrading inherent in diplomatic negotiations might detract from the coherence and comprehensiveness of the official comments. ${ }^{202}$ The resulting document might raise as many questions as it answers.

Finally, while a new set of official comments would undoubtedly improve uniformity of interpretation, it would be a document fixed in time. The CISG was intended to grow and evolve with international sales law. This can be seen in the primacy that the CISG places on the text of the contract and the customs and usages adopted between the parties or in the relevant industry. Under the CISG, these are the primary sources of law applicable to the parties, and only after the plain text, customs, and usages come the provisions of the CISG itself in settling interpretative disputes. Writes Hackney, "[I]t is natural to conceive of the Convention, based on its own terms, as an evolving set of laws, instead of one static code that has one uniform interpretation that may be applied." 203

199. JAMES J. WHite \& RoBERT S. SUMMERS, UNIFORM COMMERCIAL CODE 12 (3d ed. 1988).

200. Murray, supra note 23, at 378-79.

201. Cost was a major reason for the limited scope of UNCITRAL's efforts aimed at uniformity. Bonell, supra note 22, at 242.

202. As Bonell notes, the text of the CISG, itself, is full of compromises. "In view of the considerable differences in the legal traditions and/or in the socio-economic structures of the States participating in the negotiations, some issues had to be excluded from the scope of the CISG at the outset. Additionally, with respect to a number of other items, the conflicting views could only be overcome by compromise solutions leaving matters more or less undecided." Michael Joachim Bonell, The CISG, European Contract Law and the Development of a World Contract Law, 56 AM. J. COMP. L. 1,3 (2008).

203. Hackney, supra note 57 , at 477 . 
Therefore, a new set of official comments would not, on its own, be sufficient to ensure uniformity and may actually hinder the long-term viability of the CISG by restricting the freedom with which courts can adapt it to individual parties or changed conditions.

The other potential centralized source of interpretive guidance is a permanent, official CISG advisory board. As discussed above, UNCITRAL rejected a proposal of Bonell's that would have created such a board. ${ }^{204}$ However, given the persistence of the homeward trend phenomenon and the fact that new circumstances continue to arise for which the CISG does not supply an obvious solution, it is perhaps time to revisit the proposal.

The advisory body probably could not be truly representative, because if it included delegates from every UNCITRAL member state, it would be too large to deliberate effectively. ${ }^{205}$ One possibility, which Bonell suggested in his original proposal, is that smaller states from the same geographical area or with similar interests could appoint a common representative. ${ }^{206}$ More likely, however, such a body would be composed of a small but geographically diverse group of international sales law experts, like the Advisory Council but possibly also including practitioners, diplomats, or international civil servants.

Other than supervising the collection and dissemination of judicial and arbitral decisions under the CISG (discussed below), such an official advisory board would be responsible for rendering "interpretations of the Convention either at the request of a court or of one of the parties to a dispute or in responding to questions raised in an abstract and general manner."207 Such opinions would necessarily be persuasive authority only, as UNCITRAL has no power to bind national courts or arbitral tribunals. However, the official status of the advisory board would give its opinions significant weight.

In short, an official advisory board would probably operate similarly to the way the CISG-AC does. However, its status as the official voice of UNCITRAL would drastically alter its reception by the "consumers" of the CISG: courts, arbitral tribunals, advocates, and their clients (although academics would surely continue to debate its pronouncements). The interpretations it advances would likely be adopted, which would give it the opportunity to point out faulty interpretations by courts and arbitral tribunals before they could be followed in subsequent decisions and harden into a jurisprudence constante, or settled law. Thus, it could guide the application of the CISG in a coherent and systematicif not entirely comprehensive-manner.

204. On the reasons for UNCITRAL's decision, see supra notes 26-30 and accompanying text.

205. The same complaint could be made of the U.S. Uniform Law Commission, which contains members from each American State, the District of Columbia, and certain territories. However, even though the ULC is a large group, there are fewer American states than CISG signatories, and the American states represent much more homogeneous legal traditions. In any event, much of the ULC's work is done in committees.

206. Bonell, supra note 23, at 242.

207. Id. at 243. 
At the same time, however, such a degree of concentration of authority may not be desirable for an ever-evolving convention used around the world. Uniformity is beneficial when it converges on a superior interpretation; otherwise, it serves only to reinforce a poor outcome. ${ }^{208}$ More importantly, it may be argued that the development of CISG interpretation is best served by a multitude of courts and tribunals assaying a multiplicity of approaches. Each decision serves as a data point for the adjudications that come after it. Thus, the body of CISG knowledge gradually improves through a sort of guided trial and error, as beneficial interpretations are copied and harmful ones identified and avoided. $^{209}$

An overly centralized interpretive apparatus, such as an official advisory board, may therefore hinder improvement by stifling innovation and depriving courts and tribunals of data on the full range of possible interpretations. This is especially so in the case of conventions like the CISG, which are designed to apply to a wide variety of conditions and adapt to changing circumstances in international commerce. For this reason, Lookofsky argues that "we cannot fill the continuing need for healthy academic debate by the creation of yet another centralized (opinionative) CISG source." 210 We therefore turn next to the role of decentralized authority in the interpretation of the CISG.

As Justice Brandeis observed, in a federal system, each individual state may "serve as a laboratory ... and try novel social and economic experiments without risk to the rest of the country." 211 The same is true in the arena of international sales law. A court may proffer a novel interpretation of the CISG and, if it is judged by other courts and tribunals to be erroneous, it will cause no harm beyond the parties in the specific dispute. If however, the interpretation is found to be wise, then a consensus will build around it and the beneficial interpretation of the CISG will be promoted. It is, moreover, "simple intuition" that, if a consensus among a multitude of participants has developed, the consensus interpretation is likely to be the correct one. ${ }^{212}$

The same is true of academic opinion: a wide range of proposals may be made in scholarly publications, including many that seem outlandish. Over

208. See, e.g., Danielle Alexis Thompson, Translation of Oberlandesgericht Karlsruhe Decision of 25-06-1997 Including Commentary-Buyer Beware: German Interpretation of the CISG has led to Results Unfavorable to Buyers, 19 J.L. \& COM. 245 (2000).

209. A phenomenon known in the political science literature as "policy diffusion." See Frances Stokes Berry \& William D. Berry, Innovation and Diffusion Models in Policy Research, in THEORIES OF THE POLICY PROCESS 169 (Paul A. Sabatier ed., 1999) (setting out the theory of policy diffusion).

210. Lookofsky, supra note 57, at 194.

211. New State Ice Co. v. Liebmann, 285 U.S. 262, 311 (1932) (Brandeis, J., dissenting).

212. This intuition is formalized in the Condorcet Jury Theorem, which states that, if the probability of an individual within a group being correct is greater than $50 \%$, then the probability of a majority of the group being correct increases with each member who is added to the group. See Eric A. Posner \& Cass R. Sunstein, The Law of Other States, 59 STAN. L. Rev. 131, 136 (2006) (applying the Condorcet Jury Theorem to the use of foreign law by U.S. courts). 
time, however, mutual critical analysis within the scholarly community winnows the undesirable interpretations and consensus tends to form. This process eventually leads to survival of only the fittest interpretations.

Therefore, much may be said for simply "leaving well enough alone." While the persistence of the homeward trend demonstrates that no consensus has yet been reached on many issues, so far, there have been relatively few published decisions under the CISG. Divergent interpretations should therefore reduce over time in both number and degree: "As more case law and commentary on the Convention develops, courts will apply the Convention with more regularity ... This will bring more predictability in international sales law." "13 After all, as Posner and Sunstein remind us, "In countless domains, imperfectly informed individuals and institutions adopt a heuristic in favor of following the majority of relevant others." 214

Such decentralized interpretive evolution is only possible if judges and arbitrators routinely consider a wide range of other adjudicators' decisions. Thus, as noted above, many CISG commentators consider it their primary duty to increase the extent to which judges consult the global jurisconsultorium. ${ }^{215}$ However, consideration of foreign case law and academic commentary is only worthwhile if judges can interpret foreign materials both easily and adequately, which is often not the case.

Obviously, foreign materials are likely to be published in a foreign language. But even if a judge can understand the denotative meaning of the words in a foreign decision, differences in culture, judicial drafting style, and legal background may render foreign decisions unintelligible or, perhaps more pernicious, misleading. Finally, even if a judge were able to make good use of a range of foreign decisions, the time and difficulty of finding, deciphering, and comparing them might make even the most conscientious adjudicator abandon the undertaking. These difficulties threaten the entire CISG project:

Expecting courts to develop an international perspective by analyzing CISG applications around the world borders on the absurd. Even if all CISG cases were readily accessible, courts would still require considerable assistance to understand the legal traditions from which they emanate to begin the process of autonomous interpretation. Lawyers will continue to avoid CISG unless they are confident of their own sophisticated understanding of the Convention and their willingness to rely upon reasoned and fair applications. CISG could fail for the worst possible reason. It could fail because it could be ignored. 216

For this reason, CISG digests and other decision databases are crucial. They must and, to a large extent, do "provide access to a large amount of wellorganized CISG information compressed into a compact and readily usable

213. Hackney, supra note 57 , at 486 .

214. Posner \& Sunstein, supra note 212 , at 141.

215. See supra notes 59-60 and accompanying text.

216. Murray, supra note 23 , at 373-74. 
format."217 Indeed, there is now an abundance of material collecting and digesting CISG case law. ${ }^{218}$ Most prominent is the UNCITRAL Digest, part of the online CLOUT (Case Law On UNCITRAL Texts) database. ${ }^{219}$ This database is both comprehensive and easily accessible by practitioners; it includes a searchable archive of case abstracts, organized by article number, and reports of national correspondents-all available in each of the languages in which the CISG was promulgated. ${ }^{220}$ As the introduction to the Digest makes clear, the benefits of such projects go beyond their use by courts:

[T]he goal of uniform interpretation benefits greatly from the adequate diffusion of judicial decisions and arbitral awards, presented in a systematic and objective way. The positive effects of such material are manifold and reach beyond providing guidance during dispute resolution. For example, it provides valuable assistance to drafters of contracts under the Convention and facilitates its teaching and study. Moreover, it highlights the international nature of the Convention's provisions and thus fosters participation to the Convention by an even larger number of States. ${ }^{221}$

However, it would be foolish for UNCITRAL, the CISG-AC, or academics to restrict their role to the dissemination of case digests. The Digest reporters have a mass of case law to read and report on as concisely and quickly as possible. More importantly, the Digest "provides no critical assessment of the widely divergent positions which national courts have taken on key CISG rules."222 Inclusion of such commentaries was seen as leaving UNCITRAL vulnerable to accusations that it preferred one nation's courts to another. ${ }^{223}$ In addition, the Digest does not provide the underlying reasoning of a decision;

217. Lookofsky, supra note 57, at 181. For an overview of the various proposals for the organization of the digest, see UNCITRAL, Report of the United Nations Commission on International Trade Law on its Thirty-Fourth Session 25 June-13 July 2001, १† 386-396, U.N. Doc. A/56/17 (July 27, 2001).

218. As Rogers and Kritzer point out, "[T] he examination of case law does not reduce the importance of legislative history and scholarly commentaries when interpreting the law." Rogers \& Kritzer, supra note 4, at 227. It is therefore unfortunate that the legislative history of the CISG and scholarly commentaries on it have not been collected and digested in so comprehensive a manner as the case law. Probably the best archive of such sources is on the Pace University CISG website, which organizes commentaries according to the CISG article analyzed, http://www.cisg.law.pace.edu/cisg/text/cisg-toc.html.

219. Other free databases include UNILEX, a collection of case abstracts arranged by article and produced by the Centre for Comparative and Foreign Law Studies in Rome (available at http://www.unilex.org.). In addition, several universities have set up websites collecting and presenting case law and commentary on the CISG. The most comprehensive of these is run by the Pace University Institute of International Commercial Law (http://www.cisg.law.pace.edu /cisg/text/cisg-toc.html). Others include http://www.uc3m.es/cisg/, http://www.jura.uni.sb.de /FB/LS/Witz/cisg.htm, and http://www.cisg-online.ch/.

220. The national correspondent reports are not yet available in Chinese or Russian. For the English language site, see http://www.uncitral.Org/uncitral/en/case_law.html.

221. UNCITRAL, Introduction to the digest of case law on the United Nations Sales Convention, Note by the Secretariat, I 9, U.N. Doc. A/CN.9/592 (June 9, 2004).

222. Lookofsky, supra note 57, at 191.

223. See supra notes $29-30$ and accompanying text. 
readers must conduct their own research into why a court ruled the way it did. ${ }^{224}$ It therefore does not help to resolve divergences of opinion between different courts, except where a clear majority view has developed. ${ }^{225}$

Even if a majority view or consensus exists, an uncritical digest can lead the reader into error. A consensus among judges from around the world can still be wrong, or at least short-sighted. A frequently-cited example of a problematic majority view on the CISG involves the large body of case law holding that the applicable interest rate under the CISG is that set by the domestic law applicable by the rules of private international law. ${ }^{226}$

Case law therefore should not merely be translated, collated, and digested. Judges heeding the dictates of Article 7(1) require "knowledge of how pertinent CISG issues have been handled by others, particularly courts and commentators representing different legal traditions."227 Such information must be disseminated "in a manner capable of instructing a receptive judge or arbitrator as to which aspects of precedential authority merit being followed and which are counter to the letter and/or spirit of the CISG." 228 A digest alone cannot accomplish this.

Finally, it is important to note that the "policy diffusion" or "laboratory of the states" model described above only works properly when a large number of cases are decided and reported. Otherwise, outliers cannot be separated from mainstream decisions. Given the wide range of cases in which the CISG potentially applies, the number of published CISG decisions is small, especially in common law jurisdictions. ${ }^{229}$ Moreover, a few provisions of the CISG tend

224. Lookofsky, supra note 57, at 193. For a discussion of the (rejected) reasons for including substantive commentary in the UNCITRAL Digest and samples of what the Digest might have looked like had such commentaries been included, see UNCITRAL, Uniform interpretation of UNCITRAL texts: sample digest of case law on the United Nations Convention on Contracts for the International Sale of Goods (Vienna, 1980), Note by the Secretariat, U.N. Doc. A/CN.9/498 (April 26 2001) available at http://daccessdds.un.org/doc/UNDOC/GEN/V01/831/33/PDF/V0183133.pdf? OpenElement. For a discussion of the proper scope of the UNCITRAL Digest, see Jernej Sekolec, Digest of Case Law on the UN Sales Convention: The Combined Wisdom of Judges and Arbitrators Promoting Uniform Interpretation of the Convention, in THE DRAFT UNCITRAL DIGEST AND BEYOND 15 (Franco Ferrari, Harry Flechtner \& Ronald Brand eds., 2004).

225. Lookofsky, supra note 57, at 193 (explaining the UNCITRAL Digest "cannot help us distinguish the wheat from the chaff[,]" or precedents which are persuasive from those which are not).

226. See Ferrari, supra note 10, at 249-50 (describing "the criticism towards the large body of CISG case law" applying the interest rate of the domestic law designated by the rules of private international law of the forum).

227. Harry Flechtner, The Several Texts of the CISG in a Decentralized System: Observations on Translations, Reservations and other Challenges to the Uniformity Principle in Article 7(1), 17 J.L. \& COM. 187, 215 (1998).

228. Curran, supra note 58, at 176 (characterizing the view of Claude Witz).

229. Jacob Ziegel, The Scope of the Convention: Reaching out to Article One and Beyond, 25 J.L. \& COM. 59 (2005). In the United States, Canada, Australia, and New Zealand combined, there are only 79 published decisions under the CISG in the 17 years from the date the CISG entered into force until 2005. In the same time period, seven Westem European civil law countries surveyed by 
to be litigated repeatedly, while others arise infrequently if at all. The same is true of academic commentaries: the bulk of publications concern a small number of CISG provisions. For much of the CISG, therefore, there is little or no case law or commentary to guide the adjudicator.

\section{B. The Proper Role of the CISG-AC}

As the above analysis indicates, both overly centralized and overly decentralized interpretive systems have their drawbacks. The optimum model is, therefore, a balanced one, in which each of the CISG constituencies contributes according to its particular competencies. The question remains: what should be the role of the CISG-AC?

We propose that the benefits of a free flow of judicial and academic opinions outweigh the benefits of centrally-directed interpretation. There is little advantage to being "locked into a foolish interpretation of the Convention for the sake of uniformity."230 Moreover, as discussed above, the standard should be one of useful or functional uniformity, rather than absolute uniformity. ${ }^{231}$ As Flechtner puts it, Article 7(1) "does not mandate a doomed quest for an unobtainable [and] . . . ultimately harmful ideal.",232

The lack of any official, centralized interpretive body means that there is currently little danger that diversity of opinion will be stifled. The CISG-AC has thus far avoided taking on even a quasi-official role, being careful in each of its publications to reiterate that it is a "private initiative." However, as courts and commentators increasingly cite CISG-AC opinions as authoritative, the CISG-AC must be careful to maintain its private identity and to refrain from intimating that its opinions ought to bind any tribunal.

At the same time, it is clear that the CISG-AC speaks with greater authority than does an individual academic. The same logic which dictates that the consensus opinion of many courts is more likely to be "correct" than that of a single court leads to the conclusion that the consensus opinion of the CISG-AC members - each of them separately an expert on the CISG-is likely to be better (both in the quality of the interpretation and its persuasiveness) than the commentary of any scholar writing alone. In addition, while CISG-AC members are not intended to represent any jurisdiction or legal tradition, they were trained in a variety of legal systems. Perhaps most importantly, the CISGAC's seemingly official title and the various accoutrements of officialdom with which it presents itself mean that courts are more likely to pay attention to a CISG-AC opinion than to any other article in a scholarly journal, especially the courts of the common law countries.

Ziegel published decisions under the CISG in 765 cases. Id. at 68 .

230. Hackney, supra note 57, at 479 (citing Flechtner, supra note 226, at 211).

231. See supra notes $48-49$ and accompanying text.

232. Flechtner, supra note 227, at 205. 
We suggest that the proper role of the CISG-AC is to mediate between the other participants in the global jurisconsultorium, such that the free flow of ideas is preserved but the harms of decentralized interpretation are minimized. Thus, the CISG-AC is most helpful when it points to the better interpretation in areas where different courts or commentators disagree, when it describes an emerging consensus or jurisprudence constante, and when it elucidates CISG provisions on which there is little or no relevant case law.

Most importantly, the CISG-AC should work to remove the barriers that might deter or hinder reference by courts and arbitral tribunals to relevant foreign decisions and academic commentaries. It can do this by collecting, describing, and discussing relevant cases and scholarly publications. Even more, it does the judicial community a service by distilling its opinion into the easily-understood and easily-cited format of an official comment.

CISG-AC Opinion No. 2 (which deals with examination of the goods and notice of non-conformities) is exemplary in this respect. The opinion states its conclusions succinctly, then describes and analyzes the different domestic traditions, the drafting history of the relevant CISG articles, and the various published judicial interpretations. Finally, it includes, as an annex, a chart displaying the published court decisions in a format that permits easy comparison.

However, the opinion also appears to dodge the central questions it considers: what actually constitute reasonable times for examining the goods and for giving notice of non-conformities. It is true that determinations of reasonableness are especially sensitive to the particulars of individual cases, ${ }^{233}$ so Opinion No. 2 rightly concludes that "no fixed period ... should be considered as reasonable in the abstract." However, it gives no guidance as to how to choose from among the varying precedents, giving only a general and non-exclusive list of factors to consider. ${ }^{234}$ It is possible that such reticence was the price of consensus among the Advisory Council members. ${ }^{235}$ However, if the Advisory Council chooses to weigh in on matters like reasonable time limits that are so dependent on the facts of individual cases, it should use its authority to promote uniformity. An opinion restricted to such generalities is little more than a digest.

233. Interpreting CISG article 39, which states that notice of a lack of conformity must be given within "a reasonable time," an Italian court described the situation, characterizing article 39 as "intentionally elastic ... in terms of reasonableness, so that the degree of flexibility will be evaluated in accordance with the practicalities of each case." Sport d'Hiver Genevieve Cutlet v. Ets. Louys et Fils, Trib. Civile di Cuneo. 45/1996., translation available at http://cisgw3.law.pace.edu/cases 1960131.i3.html.

234. Opinion 2 art. $39, \S 3$ ("[S]uch matters as the nature of goods, the nature of the defect, the situation of the parties and relevant trade usages...").

235. At least one Advisory Council member has argued for a particular measure of reasonableness. Schwenzer, supra note 167, at 123 (asserting that there are "plenty of reasons to enforce the noble month as a rough guideline"). 
V. CONCLUSION: THE FUTURE OF THE CISG-AC

The CISG-AC opinions form the nucleus of a significant new source of authority on the CISG. By addressing unsettled issues and criticizing wrongly decided judicial and arbitral decisions, the Advisory Council can play an important role in the promotion of the uniform application of the CISG. The opinions' thorough discussion of the primary persuasive sources of law outlined above-legislative history, case law, and doctrine-should prove a useful tool for practitioners.

However, because the Advisory Council is a private initiative that has received no imprimatur from UNCITRAL, its authority can only come internally; that is, from the prestige of its members, the prestige of the Advisory Council itself, and-most importantly-from the persuasiveness of its opinions. The international sales law community is becoming more familiar with the CISG-AC's opinions, as evidenced by their increasing appearances in academic publications as well as in the TeeVee Toons decision. Such familiarity should breed reliance, leading to progressively increased interpretive legitimacy. In other words, it is fair to conclude that the CISG Advisory Council is in fact coming of age.

Nevertheless, (to extend the metaphor) the CISG-AC has not yet reached the prime of its life. Thus far, the institutions that have submitted requests have been those with direct personal or professional connections with Advisory Council members. For example, two requests came from committees of the New York State and City Bars, shortly after they organized a conference with the Advisory Council. ${ }^{236}$ The International Chamber of Commerce (an institution well known to the many Advisory Council members who sit as arbitrators in ICC tribunals) also runs an academic enterprise, the Institute of World Business Law, with which several Advisory Council members are or were affiliated.

When it comes to the Advisory Council's membership, there is also evidence that it is still maturing. All of the CISG-AC members were personally known to each other prior to their involvement in the CISG-AC through conferences and other professional activities. In addition, while the Advisory Council members (and the rapporteurs who are not members) represent a variety of legal backgrounds, they still come from a handful of economically developed CISG signatory states. Since seventy-three countries from every region of the world have ratified the CISG, the Advisory Council cannot now be said to represent the full CISG community. In particular, the lack of members from

236. It should be noted that, for the first of these, Opinion No. 3, the Bar Committee first approached Allen Farnsworth in his individual capacity, and he suggested that the Committee approach the Advisory Council. Mistelis interview, supra note 14. 
developing countries, especially China (where more cases are litigated under the CISG than in any other country) hurts the Advisory Council's credibility as a global interpretive body. The CISG-AC members are keenly aware of this and have sought to add additional members from developing countries. The difficulty thus far has been in finding people from such countries who are both sufficiently fluent in English (which is the lingua franca of Advisory Council meetings) and sufficiently well-versed in the CISG. ${ }^{237}$

Finally, while scholarly publications that mention the Advisory Council or cite its opinions have increased greatly in number in the last two years, their range remains limited. To date, of the thirty academic articles published in English that mention the Advisory Council, five were written by Advisory Council members themselves. Furthermore, fourteen of the thirty were published in the three English-language journals that have a particular remit to publish scholarship related to the CISG: the Journal of Law and Commerce, the Pace International Law Review, and the Vindobona Journal of International Commercial Law and Arbitration. These publications are undoubtedly followed closely by those interested in CISG doctrine, but do not have a particularly wide readership outside this community.

To a certain extent, these connections simply reflect the small, clubby world of international sales law. However, the CISG-AC cannot be considered a truly authoritative body until its opinions are solicited by institutions not directly connected with it, its members are drawn from a wider range of backgrounds, its opinions are discussed in the wider scholarly community, and-most importantly-its opinions are applied by adjudicators in a significant number of CISG signatory states.

Although academic opinion is by no means unanimous, ${ }^{238}$ many commentators support the creation of an official CISG interpretative council. ${ }^{239}$ Such a body would undoubtedly have greater legitimacy than the Advisory Council. However, for the same reasons cited by UNCITRAL when a permanent advisory board was first proposed, ${ }^{240}$ it would still be difficult to create such a body today. In addition to the hurdle of obtaining the necessary consent of member states, there is still the risk that such an institution would be

237. Id. In addition, appointment of new members from these regions or elsewhere would have to be done gradually, since both funding considerations and a desire to keep debate sharp prevent the Advisory Council from expanding beyond fifteen members.

238. See, e.g., Hackney, supra note 57, at 479-80 ("[It is] not necessary to the goal of uniformity . . . to have a body within UNCITRAL to issue opinions as to the correct interpretation of the Articles of the Convention ... doctrine and legislative history are perfectly reasonable, instructive sources and both will provide guidance to the judge looking for the proper interpretation.").

239. See Murray, supra note 23, at 374-75 (calling for an UNCITRAL "permanent editorial board with representation from every Contracting State, not only to collect material and create a comparative analysis, but to provide interpretations and illustrations of each Article of the CISG"); see also Sim, supra note 74, at 21.

240. See supra notes 33-36 and accompanying text. 
unwieldy in its operation or would stifle healthy innovation.

In the absence of such an official interpretive body, the Advisory Council has stepped forward. Even without a mandate from UNCITRAL, the Advisory Council can and does hold a singular place in the global jurisconsultorium. Through its opinions, it offers courts and tribunals an additional tool to interpret the CISG. Reference to the CISG-AC opinions is likely to continue to grow as scholars and decision-makers familiarize themselves with these opinions and as the number of opinions itself grows. In 2011, the Advisory Council will reach an important milestone: its tenth birthday. If its development persists at this rate, this date will be an opportune time to reassess whether the CISG-AC has reached its prime. 